\title{
Bienes Públicos y Registro de la Propiedad
}

\author{
Concepción Horgué Baena \\ Profesora Titular de Derecho Administrativo \\ Universidad de Sevilla
}

\begin{abstract}
Índice: I. ACCESO AL REGISTRO DE LA PROPIEDAD DE LOS BIENES PÚBLICOS. II. DOMINIO PÚBLICO Y REGISTRO DE LA PROPIEDAD. 1. Las tensiones dimanantes de diferentes sistemas de protección de los derechos. Publicidad registral versus régimen demanial. 2. Potestades de defensa de la integridad y posesión de los bienes públicos y protección de la titularidad inscrita derivada del principio de legitimación registral. 3. Principio de fe pública y titularidad demanial. III. RÉGIMEN REGISTRAL DE LOS BIENES PÚBLICOS EN LA LEY DE PATRIMONIO DE LAS ADMINISTRACIONES PÚBLICAS. 1. Obligatoriedad de la inscripción en el Registro de la Propiedad de los bienes y derechos públicos. 2. La certificación administrativa de dominio del artículo 206 LH como título formal privilegiado de inscripción. 3. Disposición de los derechos inscritos en el Registro de la Propiedad a favor de las Administraciones públicas y su régimen de inscripción. 4. Deber de colaboración de los registradores de la propiedad en defensa de la integridad de los bienes públicos.
\end{abstract}

\section{ACCESO AL REGISTRO DE LA PROPIEDAD DE LOS BIENES PÚBLICOS.}

El Registro de la Propiedad nació como instrumento para la protección de la propiedad privada, vinculado históricamente al proceso de transformación liberal de la propiedad y a la desamortización civil y eclesiástica. Quizás por ello, por encaminarse a asegurar la propiedad privada y el tráfico inmobiliario entre particulares, las primeras regulaciones de este Registro público -Ley Hipotecaria de 1861 y reglamento de desarrollo- no aludían a los bienes o derechos del Estado o de las Corporaciones públicas ${ }^{1}$. Pronto, sin embargo,

\footnotetext{
${ }^{1}$ Para una exposición detallada de las relaciones entre dominio público y Registro de la Propiedad, sus antecedentes históricos y su fundamentación doctrinal puede verse R. PAREJO GAMIR, Protección registral y dominio público. Ed. Revista de Derecho Privado, Madrid, 1975, págs. 27 y ss.
} 
el propio Estado advirtió los beneficios que determinaba la inmatriculación de sus propiedades y derechos reales sobre inmuebles, de modo que dictaría distintas normas administrativas dirigidas a lograr el acceso de los bienes públicos al Registro de la Propiedad (tanto del propio Estado como de las entonces llamadas Corporaciones civiles). Tales normas, dictadas al margen de la legislación hipotecaria, perseguían utilizar en beneficio de las propiedades públicas el sistema de protección registral pensado para los bienes de particulares, de ahí que no alumbraran reglas sustantivas propias, siendo su finalidad determinar qué bienes públicos debían inscribirse y los trámites que para lograr la inmatriculación debían seguir las distintas dependencias encargadas de su gestión y conservación.

En tal dirección destacaría el Real Decreto de 11 de noviembre de $1864^{2}$, cuyo artículo 1 disponía que los bienes inmuebles y los derechos reales que poseían o administraban el Estado y las Corporaciones civiles y se hallaban exceptuados o debían exceptuarse de la venta con arreglo a las leyes desamortizadoras "se inscribirían desde luego en los registros de la propiedad de los partidos en que radicaren". A esta regla general de inscripción de todos los bienes públicos inmuebles escaparían sin embargo algunos de ellos. En efecto, el artículo 3 de este Real Decreto de 1864 exceptuaría de la inscripción ordenada en el Registro de la Propiedad los bienes que "pertenecieran tan solo al dominio eminente del Estado, y cuyo uso era de todos, como las riberas del mar, los ríos y sus márgenes; las carreteras y caminos de todas clases, con exclusión de los de hierro; las calles, plazas, paseos públicos y ejidos de los pueblos, siempre que no sean terrenos de aprovechamiento común de los vecinos; las murallas de las ciudades y plazas; los puertos y radas, y cualesquiera otros bienes análogos de uso común y general"; excepción de acceso al Registro de los bienes de uso público y general salvo que "alguno de estos bienes cambiare de destino entrando en el dominio privado del Estado, de las provincias, de los pueblos o de los establecimientos públicos", pues entonces "sí habría de llevarse a efecto su inscripción, desde luego, si hubieran de continuar amortizados".

2 Aunque se dictaron otras disposiciones anteriores -Real Orden de 1 de febrero de 1863, y Real Decreto de 19 de junio de 1863-, la primera norma con carácter general al respecto fue el Real Decreto de 6 de noviembre de 1863, en la que se señalaba la necesidad de inscribir todos los bienes públicos, a excepción de los que se consideraba que no eran susceptibles de apropiación privada. Esta norma fue sustituida pronto por el Real Decreto de 11 de noviembre de 1964, que se convierte en la norma de referencia en la época. 
El sentido pues de la primera normativa administrativa acerca del Registro de la Propiedad y los bienes públicos fue en su momento bastante claro: la regla general consistirá en la obligatoriedad de inscribir todos los bienes públicos inmuebles en el Registro de la Propiedad, a excepción de los bienes de uso común y general a los que se les dispensa de inmatriculación, que no prohibición. Esta dispensa de acceso al Registro de la Propiedad de los bienes de uso público y general se consideraría justificada por la ostensibilidad y notoriedad de su condición pública, dado el uso común y general o público al que estaban destinados; su publicidad traería causa en la fuerza del dato fáctico, de su continuo uso por todos, de ahí que no parecieran necesitar la publicidad que dispensaba el Registro ${ }^{3}$.

Sin embargo, cuando el Reglamento Hipotecario de 1915, dictado en desarrollo de la Ley de 16 de diciembre de 1909, incorpora a la legislación registral la normativa administrativa dictada sobre bienes públicos y Registro de la Propiedad cambiará el sentido originario que había tenido la regla de acceso al Registro, al prever la nueva regulación que los bienes públicos podían inscribirse, a excepción de los bienes de dominio público. La tradicional dispensa a la inscripción de los bienes de uso público y general se convierte a partir de esos momentos en una prohibición de acceso al Registro de la Propiedad. Además, la prohibición la extiende a partir de estos momentos también a los bienes del Estado destinados a un servicio público en sentido amplio, siguiendo la noción recibida en el Código Civil de la categoría doctrinal del dominio público. La regulación de 1915 transformaría pues la regla de acceso al Registro de la Propiedad de los bienes públicos: los bienes públicos pueden inscribirse, excepto los de dominio público, tanto los bienes de uso público y general como los afectados al servicio público.

Tal regulación, con ligeras modificaciones, pasaría a la normativa registral de los años cuarenta del pasado siglo. En efecto, de un lado, la Ley Hipotecaria

${ }^{3}$ En tal sentido, resultaba clarificadora la exposición de motivos del Real Decreto de 6 noviembre de 1863: "no hay necesidad de inscribir los bienes de uso público general, como las calles, los caminos, las riberas y otros, no porque estén fuera de comercio, sino porque no están realmente apropiados, ni constituyen el patrimonio exclusivo de ninguna persona o corporación, ni es indispensable que están señalados con un número en el registro para que sea notorio su estado civil. Debe pues renunciarse a la inscripción de todos esos bienes...". La misma filosofía inspirará a normas posteriores encaminadas a ordenar la inscripción de los bienes públicos, como la comentada en el texto de 1864 con alcance general, o las dictadas para la inscripción de determinados bienes públicos en el Registro de la Propiedad, como fue el Real Decreto de 1 de febrero de 1901 para los montes públicos. Un comentario a tales normas en R. PAREJO GAMIR, Protección registral y dominio público. Ob. cit., págs. 31 y ss. 
de 8 de febrero de 1946 (LH) recogerá como derechos susceptibles de inscripción en el Registro de la Propiedad "los títulos de adquisición de los bienes inmuebles y derechos reales que pertenezcan al Estado o a las Corporaciones civiles o eclesiásticas, con sujeción a lo establecido en las leyes y reglamentos" (artículo 2.6 LH). De otro lado, se mantendrá en el artículo 5 del Reglamento Hipotecario de 14 de febrero de 1947 (RH) la exclusión de los bienes de dominio público, distinguiendo entre bienes del Estado y de los Entes locales ${ }^{4}$. Esta normativa sigue vigente en la actualidad, aunque como se expone más adelante ha sido objeto de modificaciones importantes en el tema que nos ocupa.

Por su parte, la normativa administrativa general que en estos años regulara las relaciones entre los bienes públicos y el Registro de la Propiedad seguiría también esta orientación, pues o se referirá solo a la inscripción de los bienes patrimoniales o se remitirá a lo que dispongan las normas registrales; cabe apreciar en las normas administrativas que se ocupan del tema un matiz muy importante: para los bienes públicos susceptibles de acceso al Registro de la Propiedad la inscripción se prescribe obligatoria ${ }^{5}$.

Esta situación legal servirá en su momento de fundamentación jurídica de una de las notas características del régimen jurídico del dominio público, conocida como publicidad posesoria, en virtud de la cual, se afirmaría en la doctrina científica que los bienes de dominio público cuentan con un sistema de publicidad distinto y al margen del establecido en el Registro de la Propiedad, ya que su extracomerciabilidad y la fuerza del dato fáctico que le otorga su destino público hacen innecesaria su inscripción registral ${ }^{6}$. Como se puede apreciar, según esta doctrina, la publicidad posesoria de su destino confiere al do-

\footnotetext{
${ }^{4}$ El artículo 5 RH disponía: "No obstante lo dispuesto en el artículo anterior, quedan exceptuados de la inscripción: $1^{\circ}$. Los bienes de dominio público a que se refiere el artículo 339 del Código Civil, ya sean de uso general, ya pertenezcan privativamente al Estado, mientras estén destinado a algún servicio público, al fomento de la riqueza nacional o a las necesidades de la defensa del territorio. $2^{\circ}$. Los bienes municipales y provinciales de dominio y uso público conforme a la legislación especial. 3‥ Las servidumbres impuestas por la Ley que tengan por objeto la utilidad pública o comunal...".

${ }^{5}$ Vid. el artículo 35 del derogado Reglamento de Bienes de las Entidades Locales de 1955 y el artículo 42 de la derogada Ley de Patrimonio del Estado de 15 de abril de 1964.

${ }^{6}$ Vid., entre otros M. CLAVERO ARÉVALO, "La inalienabilidad del dominio público", RAP., núm. 25, 1958, pág. 77; J.L. VILLAR PALASÍ, Apuntes de Derecho Administrativo. Tomo I, Madrid, 1977, pág. 66; J.A. GARCÍA TREVIJANO, "Titularidad y afectación demanial en el ordenamiento jurídico español”, RAP., núm. 29, 1959, pág. 18, en nota.
} 
minio público una protección superior a la que comporta la publicidad registral, de ahí que se entendiera que formaba parte del régimen exorbitante o privilegiado del dominio público ${ }^{7}$.

Sin embargo, la exclusión de los bienes de dominio público del Registro de la Propiedad ha planteado serios inconvenientes para los intereses públicos, en tanto que margina a estos bienes del sistema de protección que dispensa la publicidad registral a los derechos, singularmente el derivado de los principios de legitimación y fe pública. Pero, asimismo, la prohibición señalada ha llevado a una situación frecuentemente constatada: ha permitido que accedan al Registro de la Propiedad derechos en contradicción con la condición pública de los bienes demaniales. Basta acudir a la jurisprudencia para verificar los continuos conflictos entre la Administración pública, alegando la titularidad pública del bien en cuestión, y particulares que cuentan a su favor con una titularidad inscrita en el Registro de la Propiedad. Este dato, que no es posible desconocer, plantearía una temprana confrontación entre el sistema de protección registral de los derechos reales y el sistema de protección dispuesto para los bienes de dominio público, como veremos, que se hubiera evitado o paliado fácilmente con tener los bienes inscritos en el Registro de la Propiedad como de dominio público y titularidad administrativa. Es fácil advertir que si los bienes de dominio público no están en el Registro de la Propiedad con tal naturaleza jurídica y, por tanto, dando publicidad de su titularidad pública, no se ponen en marcha los mecanismos que el sistema arbitra para que no puedan aparecer publicadas situaciones jurídicas contradictorias a su condición y naturaleza pública.

Por esta razón, se demandaría insistentemente desde los foros más autorizados la conveniencia e incluso la necesidad de que los bienes de dominio público pudieran acogerse al sistema de protección que dispensa el Registro de la Propiedad, máxime cuando ya es difícil sostener que todos los bienes de dominio público llevan el sello de su condición jurídica, la notoriedad de su titularidad pública ${ }^{8}$. Una propuesta que ha motivado un cambio de signo en la legislación de los últimos tiempos, en una dirección clara de permitir el acceso al Registro de la Propiedad del demanio, esto es, de bienes inmuebles con tal condición jurídica y titularidad pública.

7 Vid. L. MORELL OCAÑA, Curso de Derecho administrativo. Tomo I. Aranzadi, 1997, pág. 504.

${ }^{8}$ En la doctrina, entre otros muchos: R. PAREJO GAMIR, Protección registral y dominio público. Ob. cit., pág. 79; J.M. DÍAZ FRAILE, La protección registral del litoral. Madrid, 1991. pág. 57; J.I. MORILlO VELARDE, Dominio público. Trivium. Madrid, 1992, pág. 152. 
Y así, las primeras previsiones normativas en tal dirección tienen origen en la regulación de determinados bienes de dominio público. En tal sentido, constituyó un hito importante en la regulación del Registro de la Propiedad y dominio público la Ley de Costas de 22 de julio de 1988, que en este punto dispuso la inmatriculación del dominio público marítimo-terrestre a nombre del Estado cuando se considerara conveniente ${ }^{9}$; previsión legal que siguieron, entre otras, la Ley de Vías Pecuarias de 23 de marzo de 1995 y la Ley de Aguas tras la modificación de $1999^{10}$. La reciente normativa general sobre bienes públicos también ha seguido esta orientación de habilitar el acceso al Registro de la Propiedad del demanio. Sin embargo, si la normativa especial de los bienes demaniales citados remite a la Administración correspondiente calibrar la conveniencia de instar su inscripción registral, la normativa general sobre patrimonio ha establecido la obligatoriedad de la misma para todos los bienes públicos; y así, conforme al artículo 36.1 de la Ley del Patrimonio de las Administraciones Públicas de 3 de noviembre de 2003 (LPAP):

"Las Administraciones públicas deben inscribir en los correspondientes registros los bienes y derechos de su patrimonio, ya sean demaniales o patrimoniales, que sean susceptibles de inscripción, así como todos los actos y contratos referidos a ellos que puedan tener acceso a dichos registros. No obstante, la inscripción será potestativa para las Administraciones públicas en el caso de arrendamientos inscribibles conforme a la legislación hipotecaria."

Con todo, este último precepto asume la determinación establecida en la normativa reguladora del registro de que se trate de cuáles sean los bienes públicos, tanto patrimoniales como demaniales, susceptibles de inscripción. Por esta razón, la reforma con más calado, por su alcance y significación, ha consistido en suprimir la exclusión del Registro de la Propiedad de los bienes de dominio público. En efecto, por Real Decreto 1867/1998, de 4 de septiembre,

\footnotetext{
${ }^{9}$ Conforme al artículo 13.2 de la Ley de Costas: "La resolución de aprobación del deslinde será título suficiente para rectificar, en la forma y condiciones que se determinen reglamentariamente, las inscripciones registrales contradictorias con el deslinde. Dicha resolución será título suficiente, asimismo, para que la Administración proceda a la inmatriculación de los bienes de dominio público cuando lo estime conveniente...”; por su parte, el Reglamento General de la Ley de Costas de 1 de diciembre de 1989 establecería un criterio normativo general de conveniencia respecto de "los bienes cuya publicidad posesoria no sea ostensible, así como cuando cualesquiera otras circunstancias físicas o jurídicas lo aconsejen", (artículo 29.4).

10 Tanto el artículo 8 de la Ley de Vías Pecuarias de 23 de marzo de 1995 como el actual artículo 95 del Texto Refundido de la Ley de Aguas, aprobado por Real Decreto Legislativo de 20 de julio de 2001 reproducen las previsiones de la legislación de costas al respecto.
} 
de modificación de determinados artículos del Reglamento Hipotecario se ha dado nueva redacción, entre otros, al artículo 5 que ahora establece:

"Los bienes inmuebles de dominio público también podrán ser objeto de inscripción, conforme a su legislación especial”.

En conclusión, tanto la normativa administrativa como la normativa hipotecaria, si puede hacerse tal tipo de distingo, parten ahora de la posibilidad de acceso al Registro de la Propiedad de todos los bienes públicos, sin exclusión alguna, que entren en el ámbito de aplicación que le es propio: el dominio y los demás derechos reales sobre bienes inmuebles (artículo 1 LH y, específicamente para las Administraciones públicas, artículo $4 \mathrm{RH}$ ).

\section{DOMINIO PÚBLICO Y REGISTRO DE LA PROPIEDAD}

\section{Las tensiones dimanantes de diferentes sistemas de protección de los de- rechos: publicidad registral versus régimen demanial}

Se ha señalado como el Registro de la Propiedad nació para defender la propiedad y el tráfico jurídico de los derechos reales privados, y como, también, la configuración histórica del régimen de las cosas públicas prescindiría de este Registro a la hora de diseñar las medidas para su protección. Hasta fechas relativamente recientes los bienes de dominio público han estado excluidos del Registro de la Propiedad; solución legal que se justificaba por considerarse que no necesitaban de esta institución al contar con un sistema de publicidad propio, la llamada publicidad posesoria derivada de su condición de res extracomercium. Si en un plano abstracto no presentaba problema alguno la independencia de ambos sistemas de protección de los bienes, para la propiedad privada el que dispensa el Registro de la Propiedad y para el dominio público el derivado de tal condición, en la realidad practica los hechos han sido muy diferentes. En no pocas ocasiones se han enfrentados ambos sistemas de protección, y tanto en el nivel provisional o de la posesión como en el plano de la titularidad, y en relación con concretas dependencias demaniales, como fue el caso de las costas, se generaría incluso una encendida polémica acerca de cuál sistema debía prevalecer en caso de colisión ${ }^{11}$.

\footnotetext{
11 Acerca de la colisión de ambos sistemas de protección de los bienes, y en especial la polémica doctrinal en torno a la eficacia del título inscrito en el Registro de la Propiedad sobre parcelas de la zona marítimo-terrestre puede verse nuestro trabajo El deslinde de costas. Tecnos, Madrid, 1995, págs. 240 y ss.
} 
Para entender la tensión dominio público-Registro de la Propiedad hay previamente que hacer algunas consideraciones, a la luz del hecho de que aunque en principio los bienes de uso público han estado exceptuados del Registro hasta la reforma de 1998, se han inscrito bienes de los que se predica su condición demanial. En primer lugar, si la Administración pública es la que ha inscrito a su favor la titularidad sobre un bien, haciendo constar que es de dominio público, el supuesto no plantea especiales problemas. La protección dispensada por el Registro de la Propiedad se superpone así a la prevista al margen de éste, en tanto que el dominio público no se privatiza por la inscripción. Es más, esta inscripción refuerza la posición de la Administración pública: de una parte, desplegando a su favor los medios de defensa propios del demanio y los derivados de la titularidad inscrita -principio de legitimación registral, entre otros-; de otra parte, y no menos relevante, la posición del Ente público se reafirma con la inscripción al impedir con ello el acceso al Registro de la Propiedad de titularidades privadas contradictorias. Es sabido que las normas hipotecarias ordenan al registrador que verifique un examen detenido de los índices y libros para comprobar si el derecho que se pretende inscribir se encuentra ya inscrito a favor de persona distinta, pues en este caso debe denegar sin más todo acceso al Registro de la Propiedad ${ }^{12}$. Es la inscripción a favor de particular de dependencias de dominio público el supuesto que ha dado lugar a conflictos.

Debe aclararse, sin embargo, que si en la exposición que se hace se habla de inscripciones de particulares sobre el dominio público lo cierto es que al Registro de la Propiedad no acceden titularidades privadas plenas sobre dominio público, esto es indiscutible. El particular que inscribe un derecho real de dominio sobre un inmueble no lo hace desde la consideración de que éste es demanial, sino que es titular de un derecho de naturaleza privada y perfectamente inscribible en el Registro de la Propiedad a su favor. Dicho en otras palabras, si surgen inscripciones de dominio a favor de particulares, como los hechos muestran que ha sucedido desde que se creara el sistema de protección registral, es porque se inscribe como dominio privado; en ningún caso se va a pretender inscribir a favor de un particular el dominio de un bien de naturaleza demanial, que evidentemente no podría producirse. Por ello, en caso de conflicto -al alegar la Administración pública que es un bien de dominio público- no es incongruente que el titular inscrito se acoja al sistema de protección que dispensa el Registro, e incluso que éste se despliegue a su favor al

${ }^{12}$ Entre otros preceptos vid. los artículos 17 y 20 LH y concordantes del RH. 
menos en su vertiente provisional como veremos, porque lo que el Registro de la Propiedad está protegiendo -según consta en sus asientos- no es un derecho sobre dominio público sino un derecho de propiedad de un particular sobre un bien sujeto al tráfico jurídico privado. A ello ha contribuido que el registrador de la propiedad no tenga que hacer ninguna calificación ni comprobación de la realidad material, en orden incluso a verificar si extrarregistralmente el derecho o el bien existe. Y también ha contribuido a que accedan indebidamente al Registro de la Propiedad derechos en menoscabo de los bienes públicos el dato de que hasta fechas relativamente recientes ni siquiera se exigía una constancia oficial, mediante certificación pública, de la realidad física del bien en relación con los linderos y emplazamiento, como actualmente requiere la legislación catastral y registral ${ }^{13}$, sino que eran los particulares quienes aportaban al registrador de la propiedad, y antes al notario, los datos sobre los linderos, la cabida, o el emplazamiento de la finca, entre otros.

Por esta razón, se comprende que el supuesto que efectivamente ha dado lugar a la controversia entre demanio y Registro es aquél en que el bien que la Administración pública afirma ser de dominio público y, por tanto, de titularidad pública aparece total o parcialmente inscrito como de propiedad privada de un particular. Y tal situación parece que ha podido suceder, y la jurisprudencia da buena cuenta de ello, en relación con inmuebles rústicos, en un sentido amplio: montes, playas, caminos, vías pecuarias, etc; no resulta fácil pensar, aunque no estamos en condiciones de asegurarlo, que haya accedido al Registro de la Propiedad como de propiedad privada una plaza pública urbana, por poner un ejemplo.

En los supuestos en que sobre un bien exista una titularidad inscrita a favor de un particular obstativa a la condición de dominio público que del mismo sostiene la Administración pública, se plantean dos tipos de problemas: la cuestión posesoria a que alude el principio de legitimación registral (artículos 1 y 38 LH) versus potestades de tutela posesoria de los bienes públicos; y el te-

${ }^{13}$ Y así, desde la Ley de Medidas Fiscales. Administrativas y del Orden Social de 30 de diciembre de 1996 (artículos 50 a 57) se obliga a hacer constar en el asiento, como uno más de los datos descriptivos de la finca, la referencia catastral que se le atribuya en el documento inscribible. Actualmente esta obligación de aportar el documento acreditativo de la referencia catastral de la finca para la inscripción en el Registro de la Propiedad se recoge en el artículo 9 LH y el artículo 41 de la Ley del Catastro Inmobiliario de 5 de marzo de 2004; con todo, en el caso de que se acredite que no es posible aportar la referencia catastral por estar pendiente de comunicación por el Catastro, los interesados quedan liberados de esta obligación y exentos de responsabilidad. 
ma de la titularidad del bien, en la que está en cuestión la protección dispensada al tercero hipotecario (artículo $34 \mathrm{LH}$ ), en aplicación del principio de fe pública registral, frente a la titularidad pública necesaria de los bienes demaniales.

\section{Potestades de defensa de la integridad y posesión de los bienes públicos y protección de la titularidad inscrita derivada del principio de legitimación registral}

Es conocido como al amparo de las normas que atribuían a la Administración la conservación de los bienes públicos se reconocerá a ésta la potestad de tutelar su posesión sin necesidad de acudir a los Tribunales de Justicia. La potestad de defensa posesoria se alumbraría por la jurisprudencia y las decisiones de los órganos que dirimían los conflictos de atribuciones entre la Administración y los Tribunales, y llegaría a tener su consagración positiva expresa por primera vez y con carácter general en la Real Orden de 10 de mayo de 1884. Esta norma tras recoger el principio general del derecho de que nadie puede ser privado de la posesión en que se halle sin ser oído y vencido en juicio reconocerá, como excepción a tal principio, la facultad que asiste a la Administración Pública de mantener por sí misma la posesión de sus bienes y, por extensión, recobrar la indebidamente perdida ${ }^{14}$. Desde este momento la potestad de recuperación posesoria de los bienes públicos se asentará en nuestro Derecho, y actualmente se formula como una de las potestades integrantes del régimen jurídico de las Administraciones públicas para la tutela de sus bienes (art. 55 LPAP).

Pero, asimismo, la doctrina que sustentara dogmáticamente la potestad de recuperación posesoria determinaría igualmente el alcance de los otros poderes que se van reconociendo a la Administración pública para la conservación latu sensu de sus bienes, como es el caso de la potestad de deslinde, al entenderse que todas estas prerrogativas responden al mismo poder jurídico. Ciertamente, el deslinde tiene como finalidad institucional la determinación de los confines físicos de un bien inmueble que se corresponden con una titularidad singular, pero en tal cometido la Administración pública se encon-

${ }^{14}$ Sobre el trazado histórico de la potestad de recuperación de oficio vid: V. MENDOZA OLIVAN, El deslinde de los bienes de la Administración, Tecnos, Madrid, 1968, págs. 254 y ss; M. CLAVERO ARÉVALO, "La recuperación administrativa de los bienes de las Corporaciones Locales". RAP, núm. 16, 1955, págs. 117 y ss. 
trará condicionada a las propias exigencias derivadas del poder jurídico con que cuenta para remover la situación posesoria de un tercero de forma legíti$\mathrm{ma}^{15}$.

Por ello, y atendiendo a la configuración clásica del deslinde de los bienes públicos, la Administración pública debe reflejar la situación posesoria, de modo que no podrá desconocer la posesión de un tercero que se muestre insalvable a sus poderes de tutela posesoria ${ }^{16}$. Tradicionalmente las normas y, especialmente la jurisprudencia, reconducirán al terreno de la posesión la naturaleza jurídica, y su propia eficacia, del deslinde administrativo de los bienes

\footnotetext{
${ }^{15}$ Ahora bien, que la potestad de deslinde y la de recuperación posesoria, entendida como potestad autónoma de la anterior, tengan claros puntos de conexión no significa la intercambiabilidad de las técnicas ni diluye las diferencias sustanciales entre ambas. Ante todo, porque la potestad de recuperación de oficio cuando se ejercita de forma autónoma se dirige en exclusiva al restablecimiento del bien a su situación anterior, básicamente a la reposición de la integridad del bien público afectado, y agota ahí su eficacia; mientras que el alcance institucional del deslinde es establecer la extensión y límites del bien público y declarar su estado posesorio, con una eficacia temporal indeterminada, aunque a su través también pueda llegarse a una recuperación administrativa en el caso de que con su práctica se manifestase la existencia de usurpaciones. Igualmente, aunque con ambas potestades pueda llegarse al mismo resultado, ello no significa que sea indiferente actuar una u otra en todos los casos de usurpación. De un lado, porque la represión de ocupaciones indebidas que puede realizarse con ocasión del deslinde han tenido que evidenciarse en su práctica, es decir, existe una conexión temporal entre el deslinde y la situación posesoria que se considera abusiva. La potestad de recuperación de oficio puede actuarse ante cualquier usurpación, lo que permite su consideración autónoma pues la ocupación abusiva sobre el bien público ha podido surgir mucho tiempo después de su deslinde, o antes del mismo. De otro lado, al igual que no se requiere actuar la potestad de recuperación posesoria tras el deslinde, ya que éste declara el carácter abusivo de la ocupación y requiere su cese al detentador, tampoco se exige para ejercer la potestad de recuperación de oficio que el bien esté delimitado si la Administración puede probar que la posesión que considera abusiva recae sobre un bien público. Por esta razón, la jurisprudencia sanciona que el único supuesto donde el recobro posesorio no puede actuarse mediante el interdictum propium, de forma autónoma, sino a través del deslinde del bien es precisamente cuando existen dudas sobre la identidad entre lo poseído por la Administración y lo usurpado por el particular, ya que la imprecisión de los límites del bien no permite acreditar que la posesión del particular sea una usurpación; en tal sentido, vid. SSTS de 23 de marzo de 1987 (RJ.3791) y de 3 de diciembre de 1990 (RJ.7098), así como las Sentencias del Tribunal Superior de Justicia de Cantabria de 5 de noviembre de 1999 y del Tribunal Superior de Justicia de Asturias de 31 de julio de 2000.
}

${ }^{16}$. Acerca de la configuración histórica del deslinde de los bienes públicos y su conexión institucional con la potestad de recuperación posesoria vid. nuestro trabajo El deslinde de costas. Tecnos, Madrid, 1995, en especial págs. 133 y ss. 
públicos ${ }^{17}$. El verdadero significado de esta tesis, que es la tradicional en nuestro Derecho, es sentar que la Administración en el ejercicio de las potestades de tutela de sus bienes únicamente tiene poder jurídico, sin necesidad de auxilio judicial, para realizar un pronunciamiento sobre la posesión, pues estando implicados terceros la declaración de los derechos civiles, de la propiedad principalmente, pertenece a los Tribunales de Justicia ${ }^{18}$.

Por lo demás, la consecuencia del reconocimiento de esta autoprotección posesoria será la exclusión de la tutela interdictal frente a la Administración: actuando en el ámbito legítimo de sus atribuciones los Tribunales de Justicia no pueden intervenir; y, en particular, amparar en la posesión a los terceros frente a los que la Administración ejerce las acciones de tutela posesoria. Frente al ejercicio legítimo de la autodefensa posesoria de la Administración se prohíben los interdictos de los particulares, al desaparecer la ilegitimidad de la inquietación posesoria. Como se recoge actualmente en el art.43 LPAP frente a las actuaciones en ejercicio de las potestades para la defensa de los patrimonios públicos no cabrá la acción para la tutela sumaria de la posesión prevista en el art.250.2 de la Ley de Enjuiciamiento Civil; las demandas en las que se ejercite esta pretensión no serán admitidas a trámite. De este modo, la potestad de defensa posesoria evidencia en este ámbito, el de la posesión, la delimitación funcional que se consagraría en nuestro Derecho entre la Administración y los Tribunales, toda vez que en el ámbito de la tutela posesoria no solo está exenta de impetrar la tutela de los Tribunales, sino que éstos deben inhibirse de amparar a los particulares cuando la Administración actúa en ejercicio legítimo de sus poderes.

${ }^{17}$ Esta situación posesoria que el deslinde declara se muestra en la jurisprudencia con terminología variada, confusa a veces: de posesión de facto la califica la STS de 31 de enero de 1963 (RJ.792); de estado fáctico la califica la STS de 16 de noviembre de 1972; de situación de mera tenencia en las SSTS de 28 de febrero de 1979 (RJ.700) y de 5 de noviembre de 1990 (RJ.8739); de posesión de hecho las STS de 3 de marzo de 1979 (RJ.1020) y de 22 de mayo de 1985 (RJ.2935). Lo que se pretende resaltar con distinta terminología y fortuna es que el deslinde no puede hacer pronunciamientos acerca de la titularidad de los terrenos incluidos en el mismo y que este debe ratificar la situación posesoria de la Administración, respetando aquellas situaciones jurídicas de terceros que no puede desconocer.

18 En palabras de la STS de 3 de marzo de 1992: "el deslinde no puede convertirse en una acción reivindicatoria simulada, y no puede con tal pretexto la Administración hacer declaraciones de propiedad sobre terrenos en los que los particulares ostentes derechos de propiedad y prueben una posesión, ya que el deslinde solo sirve para la fijación precisa de la situación posesoria entre las fincas deslindada" (RJ.1775); y en similares términos: las SSTS de 18 de enero de 1989 (RJ.142), de 5 de noviembre de 1990 (RJ.8739), de 7 de febrero de 1996 (RJ. 985) y de 27 de mayo de 2003 (RJ.4104). 
Es fácil advertir que si con ocasión del ejercicio por parte de la Administración pública de estas potestades de tutela de los bienes públicos, reconducidas tradicionalmente al ámbito posesorio, se opone que el bien está total o parcialmente inscrito en el Registro de la Propiedad como de titularidad de un sujeto distinto se plantea un conflicto jurídico, debido a la protección que la legislación hipotecaria dispensa al titular inscrito. En efecto, cabe recordar que el principio de legitimación registral o eficacia defensiva de los asientos (artículos 1 y $38 \mathrm{LH}$ ) significa que los asientos de los derechos inscritos presumen iuris tantum la veracidad de lo publicado, a saber, que el derecho existe, pertenece a su titular, el cual tiene la posesión del mismo; y esta triple presunción despliega sus efectos a todos los órdenes y efectos legales, sea en beneficio o perjuicio de su titular; asimismo, desde una perspectiva procesal el principio de legitimación registral exige que aquél que pretenda desvirtuar esta triple presunción, al estar los asientos del Registro bajo la salvaguarda de los Tribunales civiles, tenga que acudir y probar ante éstos la inexactitud del Registro de la Propiedad, no solo atacando el derecho publicado sino también, e indisolublemente, el asiento que los refleja, relevándose al titular inscrito de probar lo que el asiento presume.

De plantearse el conflicto, la pregunta es inevitable ¿se impone la situación jurídica del titular registral al ejercicio de la potestad de tutela de la Administración pública?, ¿cómo se manifiesta la incidencia de la situación jurídica que refleja el dominio inscrito a favor del sujeto en contradicción con la condición de dominio público esgrimida por la Administración? A nuestro juicio, no sería correcto responder a estas preguntas mediante afirmaciones rotundas y universalmente válidas en relación a todos los bienes públicos y en cualquier época, pues los matices se imponen según sea el sector de que se trate, de la normativa que en cada época fuese aplicable e, incluso, de cuál sea la potestad que ejercitara la Administración pública. Pero aún reconociendo las singularidades que puedan darse cabe realizar un intento de aproximación a este tema desde la perspectiva de la ordenación de categorías de bienes declarados de dominio público para ver si es posible formular alguna consideración general y, en su caso, excepciones a la misma.

Para realizar esta aproximación puede analizarse la cuestión en relación con los montes públicos, categoría de bienes que ha contado desde siempre con una de las regulaciones más completas en materia de deslinde y de recobro posesorio, expresiva de la importancia que en determinado momento representó la riqueza forestal pública. En tal sentido, y como ya expusimos en otro lugar, la presunción posesoria derivada de la inscripción registral del dominio -desde su formulación inicial en artículo 41 de la Ley 
Hipotecaria de 1909- plantearía desde un primer momento una colisión con las potestades de defensa de los montes públicos, e incluso una colisión con la eficacia posesoria que, desde el Decreto de 1 de febrero de 1901, otorgaba el Catálogo de Montes de Utilidad Pública ${ }^{19}$. Aunque fue un tema discutido en la doctrina, los órganos de lo Contencioso-administrativo considerarán la presunción dimanante de la inscripción del dominio en el Registro de la Propiedad prevalente a la del Catálogo, y en general prevalente a los medios de tutela reconocidos a la Administración pública para la defensa de la integridad de los bienes públicos. ${ }^{20}$ De esta forma, aunque este límite al deslinde de los montes públicos no se recogiera en la legislación forestal se impuso a la Administración con ocasión de la fiscalización de tales actos de tutela. La jurisprudencia consolidaría la doctrina de que el deslinde de montes debe respetar la situación posesoria derivada de la inscripción registral del dominio, ante la que decae la presunción del Catálogo. Si en las operaciones de deslinde se oponen títulos de dominio inscritos la Administración no tiene potestad para desconocerlos. Sería el Decreto-Ley de 1925, por el que se aprobaron las Instrucciones para la adaptación del régimen de los montes de los pueblos al Estatuto municipal y sus reglamentos, la primera norma forestal que expresamente sancionaría el respeto en las operaciones de deslinde de los títulos de dominio inscritos en el Registro de la Propiedad. Este límite se recogería para el deslinde de los montes catalogados en la Ley de Montes de 1957, al prescribir en el artículo 14.b la eficacia y el valor de los títulos de dominio inscritos en el acto de apeo de los montes catalogados. Por su parte, la jurisprudencia muestra la contundencia con la que los Tribunales del orden Contencioso-administrativo han sancionado la nulidad de los actos de deslinde de montes públicos que hubieran abarcado terrenos que figuran en el Registro de la Propiedad como de titularidad de un sujeto que no es la Administración que esgrime su pertenencia, por desconocimiento de la presunción de existencia, titularidad y

${ }^{19}$ Sobre la configuración histórica, evolución normativa y significación de las potestades administrativas para la protección de la integridad de los montes públicos y el entendimiento que dieran los Tribunales vid. nuestro trabajo "Las potestades administrativas para la protección de los montes públicos", en la obra colectiva coordinada por L. CALVO Comentarios sistemáticos a la Ley 43/2003, de 21 de noviembre, de Montes. Estudios de Derecho forestal estatal y autonómico. Thomson-Cívitas, 2005 , págs. 569 y ss.

${ }^{20}$ Entre otras, SSTS 24 de abril de 1914, 2 de marzo de 1915, 5 de mayo de 1917, 18 de octubre de 1928, 16 de abril y 1 de diciembre de 1921, recogidas en nuestro trabajo "Las potestades administrativas para la protección de los montes públicos”. Ob. cit., pág. 619. 
posesión de los derechos de dominio inscritos ${ }^{21}$. Las únicas exigencias que ha mantenido el Tribunal Supremo para aplicar esta doctrina son, de un lado, que el particular haya aportado los títulos inscritos en el procedimiento de deslinde pues en otro caso la Administración no puede tener los elementos de juicio suficientes para el señalamiento de límites. De otro lado, que el inmueble sobre el que recae la titularidad inscrita esté plenamente identificado e individualizado sobre el terreno, de tal forma que no exista incertidumbre alguna acerca de su situación y linderos ${ }^{22}$.

Por lo demás, cabe señalar que los Tribunales de lo contencioso-administrativo aplican la misma doctrina para la potestad de recuperación de oficio en sentido autónomo, al considerar que las titularidades inscritas de dominio en el Registro de la Propiedad de quienes ocupan el terreno forestal enervan el presupuesto en el que se asienta el ejercicio legítimo de esta potestad, esto es, que tal situación por parte del titular inscrito sea una usurpación ${ }^{23}$.

${ }^{21}$ Entre otras muchas: SSTS de 28 de febrero de 1979 (RJ.700), de 11 de mayo de 19832930 y de 10 de noviembre de 1983 (RJ. 6533), de 4 de noviembre de 1991 (RJ. 8160).

22 Como se señala en la STS de 11 de julio de 1977: "las presunciones posesorias derivadas de los títulos inscritos que invocan los recurrentes podrían fundamentar la impugnación, siempre y cuando la claridad y concordancia con el terreno... concretasen unos límites que pudieran servir de base a su reconocimiento por el órgano resolutorio" (RJ.3517), o según la STS de 24 de mayo de 1977 la eficacia de la inscripción registral no opera "cuando el terreno debatido excede de la extensión superficial consignada en la escritura" (RJ.3324). Exigiendo la identificación e individualización de la finca según los datos del asiento registral de dominio para su oponibilidad al deslinde vid: SSTS de 15 de octubre de 1979 (RJ.3449), 25 de enero de 1979 (RJ.208) y 10 de noviembre de 1983 (RJ.6533).

${ }^{23}$ En este sentido, los Tribunales señalan que las titularidades inscritas de dominio prevalecen incluso frente a la presunción posesoria del Catálogo, de ahí que enerven la legitimidad de cualquier actuación que requiera como presupuesto la consideración de que el terreno de que se trate es un monte público. Esta doctrina se aplica tanto para los casos en que la Administración ejercite su potestad de recobro posesorio (STS 19 de diciembre de 1986), como la potestad sancionadora (STS de 22 de noviembre de 1979, Sentencias del Tribunal de Justicia de 1 de junio de 1999 -Castilla-León-y de 25 de mayo de 1996 -La Rioja), o incluso cuando se refiere a acuerdos sobre la disposición de los aprovechamientos del monte (STS de 7 de diciembre de 1981, RJ.5367). 
Finalmente, resaltar que la misma previsión acerca del respeto por parte de la Administración pública de las inscripciones registrales se recoge actualmente en el artículo 21.5 de la Ley Básica de Montes de 2003 para el deslinde de los montes de titularidad pública, tanto para los declarados de dominio público como para los patrimoniales ${ }^{24}$. Por consecuencia, puede sostenerse la continuidad en la nueva Ley de Montes de la configuración tradicional de las potestades de deslinde y de recuperación posesoria sobre los montes públicos y con ello del valor obstativo que presentan los títulos de dominio inscritos en el Registro de la Propiedad.

Más allá de montes, la normativa sobre bienes públicos no ha reflejado la inscripción registral de dominio como límite o hecho obstativo a la potestad de deslinde o a la potestad de recuperación posesoria, ni tampoco ahora se recoge en la regulación que de estas potestades realiza la nueva Ley de Patrimonio de las Administraciones Públicas de 2003 en los artículos 41 y siguientes ${ }^{25}$. Tal límite, sin embargo, ha sido mantenido con carácter general por los Tribunales del orden contencioso-administrativo: la Administración debe respetar las situaciones jurídicas que publican los asientos del Registro de la Propiedad, pues en otro caso se excede de sus competencias, sería una acción extramuros de su potestad. Esta doctrina se aplicará pues a la potestad de deslinde ${ }^{26}$, y al ejercicio de la potestad de recuperación de ofi-

\footnotetext{
${ }^{24}$ Acerca del alcance de la normativa básica de montes vigente, así como las previsiones al respecto en la legislación autonómica forestal vid. "Las potestades administrativas para la protección de los montes públicos”. Ob. cit., págs. 621 y ss.

${ }^{25}$ La única excepción que puede señalarse es la confusa referencia que el artículo 6 de la derogada Ley de Costas de 1969 hacía al artículo 34 LH como límite al deslinde de la zona marítimo terrestre, aunque los Tribunales siguieron aplicando en esos años la doctrina que se expone en el texto, vid. El deslinde de costas. Ob. cit., págs. 230.

${ }^{26}$ Vid. En relación con el deslinde de bienes de las Entidades Locales (SSTS de 8 de junio de 1977 (FJ.3242), de 5 de junio de 1987 (RJ.6006), de 5 de noviembre de 1990 (FJ.8739); de bienes patrimoniales del Estado (SSTS de 18 de enero de 1989 (RJ.142), de 3 de marzo 1992, (RJ.1775) de 7 de febrero de 1996, (RJ.985); de caminos públicos (SSTS de 10 de febrero de 1988 (RJ.1401) y de 8 de julio de 1998 (RJ.6095); y también en relación con el deslinde de vías pecuarias (SSTS 10 de febrero de 1989 (FJ:998) y de 3 de junio de 1991 (RJ.6759) y del deslinde de zona marítimo-terrestre (SSTS de 22 de septiembre (RJ.1670), y de 18 de mayo de 1977 (FJ.2209) hasta la nueva regulación. No obstante, en relación con el deslinde de vías pecuarias la jurisprudencia ha sido vacilante a la hora de sancionar el límite de las inscripciones registrales, existiendo pronunciamientos tanto admitiendo este límite como negándolo; al respecto puede verse un detallado análisis de las decisiones judiciales en ambos sentidos en M.A. PARRA LUCAN, Vías pecuarias y propiedad privada. DyKinson, 2002, págs. 130 y ss.
} 
$\operatorname{cio}^{27}$. Y lo que es singularmente importante: el respeto a los derechos inscritos en el Registro de la Propiedad por parte de la Administración pública es una doctrina sostenida por los Tribunales de lo contencioso-administrativo abstracción hecha del carácter demanial o patrimonial de los bienes que esgrime la Administración pública; a diferencia de lo que supuso para los bienes de dominio público la ruptura del plazo del año y un día para entender legítima la remoción de la posesión indebida, de un tercio, tal como actualmente refrenda el artículo 55.2 LPAP.

Y es que el fundamento que sustenta esta doctrina radica en la salvaguarda por los Tribunales de Justicia, y hoy por los del orden civil, de los derechos inscritos en el Registro de la Propiedad (artículos 1 y 38 LH). De este modo, el respeto a la presunción de existencia, titularidad y posesión dimanante de los asientos registrales marcan el ámbito legítimo del ejercicio de la potestad de deslinde de los bienes públicos y cualquier otra actuación que requiera como presupuesto la condición pública del bien, de manera que su desconocimiento por la Administración pública supone una extralimitación de sus competencias, ya que no tiene potestad para desvirtuar lo publicado en el asiento registral fuera de los Tribunales civiles. En tales términos, la cuestión se reconduce a una delimitación funcional que en un momento histórico decantó nuestro Derecho entre la Administración y los Tribunales pues, en estos supuestos, por prescripción legal expresa (artículos 1 y $40 \mathrm{LH}$ ), corresponde a los Tribunales ordinarios con exclusividad entrar a conocer si la realidad extrarregistral se corresponde o no con lo publicado en el Registro de la Propiedad. Lo cual se muestra como una derivación de otro principio del alcance más general, el monopolio del Juez civil para dirimir los conflictos sobre propiedades, al que corresponde el pronunciamiento definitivo de a quién pertenece el derecho, la titularidad. Por la misma razón, debe advertirse que la titularidad inscrita en el Registro de la Propiedad se impone a la Administración pública en su acción de tutela, con independencia de lo que pueda llegar a decidirse en sede judicial y en el juicio plenario correspondiente acerca de la titularidad del bien.

\footnotetext{
27 SSTS de 6 de junio de 1988 (RJ.4593), de 23 de marzo de 1987 (RJ.3791), de 5 de junio de 1987 (RJ.6096), de 5 de noviembre de 1990 (RJ.8739); orientación seguida también por los fallos de los Tribunales Superiores de Justicia: de 31 de julio de 2000 (TSJ de Asturias), de 7 de noviembre de 2003 (Cataluña), de 26 de septiembre de 2003 (de Andalucía) y de 8 de septiembre de 2003 (Castilla y León).
} 
Ahora bien, aparte de las consideraciones dogmáticas que pudieran esgrimirse e incluso del arraigo que esta doctrina presenta en nuestro sistema jurídico, la eficacia de la inscripción de dominio de un particular frente al ejercicio de las potestades de tutela de los bienes públicos tiene su fundamento jurídico en la normativa registral, esto es, en la medida que tienen plena aplicación los artículos 1 y 38 LH en el sentido señalado. Por esta razón si existe una normativa, con rango suficiente, que contrarreste la eficacia defensiva de la inscripción registral, la Administración pública no se ve constreñida a detenerse ante un derecho inscrito en el Registro de la Propiedad en el ejercicio de sus potestades de defensa de la integridad de los bienes públicos.

Este es el caso de la normativa vigente de costas, que otorgaría al deslinde del dominio público marítimo-terrestre un alcance y efectos desconocidos hasta el momento en el régimen de tutela de los bienes públicos, a fin de dispensarle la máxima protección. En efecto, el artículo 13 de la Ley de Costas de 1988 establece que el deslinde "declara la posesión y titularidad dominical a favor del Estado, dando lugar al amojonamiento y sin que las inscripciones del Registro de la Propiedad puedan prevalecer frente la naturaleza demanial de los bienes deslindados". Como puede comprobarse, la Ley de Costas dota al deslinde de una naturaleza declarativa de la titularidad pública de los bienes, lo cual implica un apartamiento radical de la legislación tradicional sobre costas y la legislación general sobre patrimonios públicos, amén de la doctrina imperante en los Tribunales del orden contencioso ${ }^{28}$. Como manifestación del alcance que la Ley de Costas dota al deslinde, tratándose de bienes de dominio público marítimo-terrestre las inscripciones registrales que publiquen derechos de particulares en contradicción con la naturaleza y titularidad demanial de los mismos no serán obstáculos al ejercicio de esta potestad, ahora solo condicionada a reflejar con el deslinde la extensión que en cada lugar concreto de nuestras costas presenten los bienes marítimos. Se excepciona, pues, en relación con el demanio marítimo-terrestre la específica protección que el artículo 1 en conexión con el artículo 38 LH establece para los derechos inscritos: que los asientos están bajo la salvaguarda de los Tribunales, desplegando todos sus efectos mientras no se declare su inexactitud.

\footnotetext{
${ }^{28}$ Para una exposición detallada de la novedosa configuración jurídica del deslinde del dominio público marítimo-terrestre en la Ley de Costas 28 de julio, vid. nuestro trabajo El deslinde de costas. Ob. cit. 331 y ss.
} 
Además, la Ley de Costas no se detiene en otorgar al deslinde el alcance de declarar la naturaleza y titularidad demanial de los bienes abarcados en su perímetro si no que, dando un paso más, le confiere la fuerza de rectificar las situaciones registrales contradictorias, lo cual implica una quiebra, más importante si cabe, al sistema de protección que dispensa el Registro de la Propiedad. En efecto, al estar los derechos inscritos bajo la salvaguarda de los Tribunales civiles, la legislación registral sólo admite la rectificación de los asientos que los publican por los cauces en ella previstos, que pueden aunarse en dos vías: aquellos en los que participa la anuencia del titular del derecho inscrito, o cuando viene impuesta por sentencia judicial firme (artículos 39 y $40 \mathrm{LH}$ ). No hay que hacer especial hincapié en la trascendencia que supone la fuerza rectificadora del deslinde de costas, que apunta a la médula del sistema de protección de los derechos basado en la publicidad del Registro de la Propiedad, aún reconociendo que la normativa reglamentaria matizaría bastante la fuerza del deslinde para la rectificación de los asientos registrales contradictorios ${ }^{29}$. Y, desde luego, tampoco pasa inadvertido la redefinición que la novedosa configuración del deslinde de costas y su eficacia implica de la posición jurídica de la Administración titular por relación con los Tribunales al amparar que pueda, con la oposición de un sujeto cuya titularidad protege el Registro, declarar mediante este acto administrativo a quien corresponde la titularidad de los bienes. A salvo, claro es, del dato de que la decisión definitiva sobre la titularidad discutida corresponda a los Tribunales de justicia, como se verá.

A nuestro juicio, sin embargo, esta configuración del deslinde de costas tiene su fundamento en la declaración de la Ley de Costas, con amparo en el propio artículo 132.2 de la Constitución ${ }^{30}$, de que cualquier bien que reúna los caracteres naturales que identifican a los bienes marítimos integra el dominio público marítimo-terrestre. En este sentido, la Ley hace inseparable la presencia de los caracteres constitutivos de la incorporación de un bien al dominio público marítimo-terrestre y la naturaleza jurídica demanial y titularidad pública. La eficacia del deslinde de costas es consecuencia de la interdic-

${ }^{29}$ En efecto, conforme al procedimiento diseñado en el artículo 29 del Reglamento General de Costas para la rectificación de los asientos contradictorios el titular registral cuenta con un año tras la notificación de la anotación preventiva de deslinde para lograr en los Tribunales una anotación preventiva de demanda contra el Estado, en cuyo caso habrá de estarse al resultado del juicio correspondiente.

${ }^{30}$ Según el cual "Son de dominio público estatal los que determine la ley y, en todo caso, la zona marítimo-terrestre, las playas, el mar territorial y los recursos naturales de la zona económica y la plataforma continental". 
ción de que puedan existir otros derecho u otras titularidades incompatibles con la demanial del Estado sobre los bienes marítimos, con independencia claro está, de que sean los Tribunales a quienes les corresponda enjuiciar si es legítima esta concatenación que mediante la operación de delimitación realiza la Administración. El valor preferente del deslinde frente a las inscripciones registrales de dominio contradictorias puede encontrar su justificación en la extinción que opera la Ley de Costas de tales derechos de dominio si recaen sobre bienes marítimos, permitiendo la adecuación de los asientos del Registro de la Propiedad con la realidad extrarregistral.

Hay que tener presente, por consiguiente, que si esta declaración de titularidad estatal implica la supresión de la legítima titularidad de un tercero la cuestión deba situarse en un plano distinto, exigiendo que la efectiva expropiación que realiza la Ley de Costas sea justamente compensada, tal como prescribe el artículo 33 de la Constitución. A ello dirige la Ley las previsiones compensatorias dispuestas en su disposición transitoria primera, al punto de disponer la conversión de las titularidades legítimas en una concesión por los usos y aprovechamientos existentes por un plazo de hasta sesenta años sin pago de canon alguno; conversión compensatoria por la expropiación realizada por la Ley de Costas que fue considerada conforme con la Constitución por el Tribunal Constitucional en Sentencia 149/1991, de 4 de julio ${ }^{31}$.

Si se repara en las consideraciones anteriores, que a nuestro juicio dan sentido a la eficacia y alcance del deslinde del demanio marítimo-terrestre, se aprecia que descansan en dos premisas claras: de un lado, en la demanialidad necesaria de los bienes marítimos definidos por remisión a sus características naturales, de suerte que cualquier terreno que presente esta identidad integra por la fuerza de la ley el dominio público; la segunda, en el dato de que de existir titularidades legítimas deba exigirse constitucionalmente una compensación indemnizatoria por la expropiación que la premisa anterior implica. Por ello, la novedosa configuración del deslinde de costas puede resultar difícil de justificar en relación con otros bienes públicos en los que tales premisas no se muestren claramente.

31 Vid. un análisis detallado del tratamiento de las titularidades privadas preexistentes dado por la Ley de Costas y las consideraciones vertidas por el Tribunal Constitucional para entenderlo conforme con la Constitución en El deslinde de costas. Ob. cit., págs. 266 y ss. 
El alcance y eficacia que al deslinde del dominio público marítimo-terrestre otorgara la Ley de Costas de 1988 se ha extendido a otros sectores. Y así, en términos casi literales al artículo 13 de la Ley de Costas se pronuncian la Ley de Aguas para el deslinde del dominio público hidráulico (artículo 95) y la Ley de Vías Pecuarias para el deslinde de las vías pecuarias (artículo 8), y de forma sintética se remite al primero el artículo 47 de la Ley de Régimen económico y prestación de servicios en los Puertos de Interés General, de 26 de noviembre de 2003, para el deslinde del dominio portuario. Congruentemente con la opinión sustentada, no nos parece que pueda tener la misma justificación la novedosa regulación del deslinde de costas en los casos en que los bienes de dominio público requieran para adquirir esta naturaleza jurídica un acto singular de afectación porque ello muestra que antes del mismo no es posible distinguir estos bienes de otros de los particulares, como es el caso por ejemplo para las vías pecuarias del acto de clasificación ${ }^{32}$.

Si ello es así, si una finca puede ser tanto de dominio público como de propiedad privada de particulares porque la condición jurídica de pertenecer al dominio público requiere un acto de afectación singular y expresa, de manifestarse un conflicto de títulos, y especialmente si existe un título de dominio inscrito en el Registro de la Propiedad a favor de un tercero, puede sostenerse que sería más conforme con nuestro sistema jurídico que se dirimiera ante los Tribunales, en el sentido de que en el terreno provisional de la posesión la Administración tuviera que respetar la situación jurídica y de hecho de la posesión del titular registral. El ejemplo de la regulación de los montes públicos puede ser ilustrativo.

Para finalizar, deben realizarse dos observaciones. La primera consiste en que, a nuestro juicio, esta novedosa configuración de la potestad de deslinde y las consecuencias que arroja sobre los derechos inscritos en el Registro de la Propiedad no cabe extenderla sin más a otras potestades de tutela, singularmente a la facultad de recuperación de oficio de forma autónoma. Como ya

\footnotetext{
${ }^{32}$ En el sentido de entender que no puede sustentarse con el mismo fundamento la regulación del deslinde para los bienes del dominio público natural, tal es el caso del dominio público marítimo-terrestre y del dominio público hidráulico, que para los bienes de dominio público por mor de un acto de afectación singular vid. el sugestivo trabajo de E. GARCÍA DE ENTERRÍA, "Inscripción registral y facultades de recuperación posesoria por la Administración”, REDA, núm. 129, 2006, págs. 117 y ss. Singularmente para las vías pecuarias se muestran críticos en relación con la nueva regulación del deslinde: O. HERRAIZ SERRANO, Régimen jurídico de las vías pecuarias. Comares, Granada, 2000, pág. 18; J.F. ALENZA GARCÍA, Vías pecuarias. Cívitas, Madrid, 2001, págs. 174 y ss; M. PARRA LUCAN, Vias pecuarias y propiedad privada. Ob. cit., págs. 177 y ss; J.A. CARRILLO DONAIRE, "La intervención administrativa sobre las vías pecuarias", RAAP, núm. 59, 2005, págs. 25 y ss.
} 
sostuvimos en otra ocasión, debe distinguirse entre dominio público marítimo-terrestre con deslinde aprobado o no, y que en el supuesto de que sobre el bien o parcela discutida no exista el acto de delimitación que acredite su condición demanial las inscripciones registrales a favor de un sujeto enervarían el ejercicio de la facultad de recobro posesorio. A nuestro entender, si la Administración entendiera que existen situaciones jurídicas amparadas por una inscripción registral que son contrarias a la naturaleza demanial de los bienes, el procedimiento que debe iniciar es el de deslinde, o el de modificación del existente si el realizado no abarca en su totalidad los bienes marítimos; porque acudir a un procedimiento sumario como es el interdictum propium para remover la situación posesoria menoscabaría las debidas garantías que la Ley de Costas reconoce a los titulares registrales, sería, en definitiva, instar un procedimiento distinto del legalmente previsto $^{33}$.

La segunda observación hace relación con el hecho de que esta declaración de demanialidad que realiza el deslinde de costas, y actualmente también para los bienes del dominio público citados, no desdibuja el dato cierto de que los titulares inscritos afectados puedan ejercer las acciones que estimen pertinentes en defensa de sus derechos, como demanda el derecho fundamental a la tutela judicial efectiva. Como no podía ser de otro modo, la reserva de acciones en defensa de los derechos de los titulares registrales es reconocida por la normativa de costas, al igual que de vías pecuarias y de aguas, que además prescriben que las acciones judiciales son susceptibles de anotación preventiva en el Registro de la Propiedad (artículos 13 de la Ley de Costas, 8 de la Ley de Vías Pecuarias y 95 de la Ley de Aguas).

La cuestión se desplaza pues a saber en qué casos pueden encontrar amparo una pretensión dirigida a un pronunciamiento favorable a la titularidad privada en los supuestos que el deslinde del bien, al admitirse por las normas, declare la titularidad pública, y por la materia objeto de este estudio, a saber si una pretensión tal puede traer causa en la protección que el Registro de la Propiedad dispensa al tercero, en virtud del principio de fe pública. Igualmente, cabe preguntarse si el principio de fe pública sirve para fundamentar una titularidad privada sobre un bien que la Administración pública pretende que se declare su pertenencia al dominio publico, si es la Administración quien debe ejercitar la acción judicial por existir una titularidad registral que se muestra insalvable a su acción de tutela posesoria, al publicar el Registro de la Propiedad el dominio de un sujeto distinto.

33 Vid. El análisis de la cuestión en El deslinde de costas. Ob. cit., pág. 397 y ss. 


\section{Principio de fe pública y titularidad demanial}

En este punto se trata de responder si la eficacia ofensiva de los asientos registrales, esto es, la protección dispensada al tercero que confía en la publicidad del Registro de la Propiedad conforme al artículo 34 LH, tiene aplicación frente a la condición pública del bien que esgrime en contrario la Administración o, en sentido inverso, si tiene aplicación para sustentar la propiedad privada si es el particular quien acciona la pretensión frente a la titularidad pública declarada por la Administración. Se enfrentan así la protección dispensada por nuestro sistema al tercero hipotecario -adquirente oneroso de buena fe de quien aparece en Registro como titular y con facultades para transmitir e inscribe a su nombre ${ }^{34}$ - y los caracteres que acompañan a la condición de dominio público de los bienes con la finalidad de asegurar el destino a los que están afectados: inalienabilidad, imprescriptibilidad, e inembargabilidad, en garantía de la titularidad pública necesaria.

La solución acerca de qué régimen debe prevalecer ha sido debatida en la doctrina, y desde luego muy enturbiada por el dato, ya visto, de que la inscripción registral de los bienes demaniales de uso público no se admitiese. Con carácter general, para los autores que parten de que los bienes de dominio público no tenían acceso al Registro de la Propiedad la cuestión tenía una solución clara: si los bienes de dominio público no entran en el ámbito del sistema no pueden aplicársele los principios registrales, y en especial el de fe pública $^{35}$; por el contrario, los que consideraron que el demanio podía acceder al Registro de la Propiedad reconocían que la cuestión distaba con mucho de

\footnotetext{
34 Según el art. 34 LH: "El tercero que de buena fe adquiera a título oneroso algún derecho de persona que en el Registro de la Propiedad aparezca con facultades para trasmitirlo, será mantenido en su adquisición, una vez que haya inscrito su derecho, aunque después se anule o resuelva el del otorgante por virtud de las causas que no consten en el mismo Registro. La buena fe se presume siempre mientras no se pruebe que conocía la inexactiud del Registro. Los adquirentes a título gratuito no gozarán de más protección registral que la que tuviese su causante o transferente". En cuanto al alcance del art. 34 LH vid. CHICO ORTIZ, J., Estudios sobre Derecho Hipotecario, t. II, Marcial Pons, Madrid, 1982, págs. 320 y ss; L. DÍEZ PICAZO-A. GULLÓN BALLESTEROS, Sistema de Derecho Civil. Tecnos, Madrid, 1985, págs. 320 y 328.

35 Vid. M. CLAVERO ARÉVALO, en "La inalienabilidad del dominio público. Ob. cit., págs. 78 y ss; V. MENDOZA OLIVAN, El deslinde de los bienes de la Administración. Tecnos, Madrid, 1968, págs. 207-208; R. FORNESA RIBÓ, en "Eficacia del título hipotecario sobre parcelas de zona marítimo-terrestre". $R A P$, núm. 46, 1965, págs. 123 y ss.
} 
tener una respuesta satisfactoria ${ }^{36}$. Ahora bien, se aprecia que incluso después de la reforma de 1998 del Reglamento Hipotecario (artículo 5 RH), se mantiene el debate acerca de si puede un tercero quedar protegido en su adquisición, conforme al artículo $34 \mathrm{LH}$, cuando se trata de bienes de dominio público, lo cual es signo de la dificultad de respuesta al tema planteado.

En efecto, si se acude a la doctrina hipotecarista se aprecian dos tesis contrapuestas. La primera tesis consiste en afirmar que el principio de fe pública registral no tiene aplicación en relación con los bienes de dominio público, haciendo especial hincapié en el argumento de la inalienabilidad de estos bienes, que se superpone a los principios hipotecarios. En tal sentido, cierta doctrina considera que el régimen de dominio público dispuesto en el artículo 132.1 CE, especialmente la regla de la inalienabilidad, no queda alterado por la Ley Hipotecaria aunque el bien haya sido inscrito y, en consecuencia, los actos de disposición de un bien de dominio público no producen respecto de tercero los efectos del artículo $34 \mathrm{LH}^{37}$, o se argumenta que frente a los bienes de dominio público no puede prevalecer la condición de tercero pues la fe pública no aporta nada a su eficacia frente a todos, que deriva directamente de la Ley ${ }^{38}$. Por el contrario, para otro sector de la doctrina, la inoponibilidad de la figura del tercero del artículo $34 \mathrm{LH}$ al dominio público era una tesis correcta cuando estos bienes no eran inscribibles, pero ahora como el Registro de la Propiedad ya no rechaza la inscripción de los bienes de dominio público deberán estos quedar sometidos al régimen ordinario de garantía de los derechos que el mismo Estado ha establecido para todos, reserva hecha para los casos en que exista una normativa específica que afronte directamente la cuestión ${ }^{39}$.

36 Vid. R. PAREJO GAMIR, Protección registral y dominio público. Ob. cit., pág. 172 y ss.

${ }^{37}$ En tal sentido R. EGEA IBÁÑEZ en "Actos administrativos y Registro de la Propiedad. Calificación Registral. Los efectos de la inscripción de los actos administrativos: principio de legitimación y fe pública registral. Notificación y publicidad de los actos administrativos", en Boletín del Colegio Nacional de Registradores, núm. 307, 1994, pág. 10.

38 P. DE PABLO, en "Artículo 39 de la Ley Hipotecaria", en Comentarios al Código Civil y Complicaciones forales. (Dir. M. ALBADALEJO y S. DÍAZ ALABART). Edersa, Tomo VII, 1999, pág. 845.

39 Vid. M. PEÑA BERNARDO DE QUIRÓS, Derechos Reales. Derecho Hipotecario. Tomo II, Centro de Estudios Registrales. Madrid, 2001, págs. 632 y ss. 
Realmente, la pregunta acerca de si la figura del tercero hipotecario del artículo $34 \mathrm{LH}$ es de aplicación aunque se trate de un bien o parte del mismo de naturaleza demanial dista de tener una respuesta clara y unívoca, además de válida abstracción hecha de la normativa que en cada momento ha regulado los distintos bienes de dominio público. No puede perderse de vista el hecho incuestionable de que la normativa histórica de ciertos bienes de dominio público hacía referencia a derechos legítimamente adquiridos, como fue el caso de la legislación de costas y de vías pecuarias. Lo único que puede sostenerse con alguna consistencia es, de un lado, que la respuesta solo puede encontrarse en los Tribunales de Justicia. En efecto, los pronunciamientos que abordan el tema de la protección del tercero en base al principio de fe pública registral -al establecer el sistema una presunción iure et de iure de lo publicado en el asiento- provienen del orden civil, al tener los Tribunales civiles reservada la competencia para conocer de la titularidad del bien litigioso, y la correspondiente rectificación registral en su caso ${ }^{40}$. De otro lado, resulta evidente que no es posible llegar a afirmaciones válidas, en respuesta a la pregunta planteada, para todos los bienes de dominio público, porque se dan matices, particularidades y claves que no pueden extrapolarse de un sector normativo a otro distinto. Como botón de muestra pueden escogerse dos sectores o categorías de bienes de dominio público: costas y vías pecuarias.

En relación con el dominio público marítimo-terrestre, la pregunta acerca de la admisión del tercero hipotecario del artículo 34 LH debe situarse en unas coordenadas temporales precisas, habida cuenta de la distinta orientación que sobre el tema de la legitimidad de la propiedad privada sobre bienes marítimos presentaron las normas históricas y la que porta la legislación vigente.

${ }^{40}$ La exclusiva competencia del orden jurisdiccional civil para conocer de los derechos de propiedad ha sido una constante en nuestro sistema jurídico, como actualmente recoge la Ley Orgánica del Poder Judicial (artículo 9), incluso cuando el conflicto surge con ocasión del ejercicio de una potestad administrativa de tutela de los bienes públicos; lo cual deriva en una dualidad jurisdiccional para conocer de las pretensiones que contra los mismos se esgrimen. En tal sentido es expresivo el artículo 43.2 LPAP: "Los actos administrativos dictados en los procedimientos que se sigan para el ejercicio de estas facultades y potestades que afecten a titularidades y derechos de carácter civil sólo podrán ser recurridos ante la jurisdicción contencioso-administrativa por infracción de las normas sobre competencia y procedimiento, previo agotamiento de la vía administrativa. Quienes se consideren perjudicados en cuanto a su derecho de propiedad u otros de naturaleza civil por dichos actos podrán ejercitar las acciones pertinentes ante los órganos del orden jurisdiccional civil...” 
Es conocido que las normas que regularon estos bienes antes de la vigente Ley de Costas de 1988 salvaguardaron "los derechos legítimamente adquiridos" en el propio precepto que sancionaba la condición pública de la zona marítimo-terrestre (Leyes de Puertos de 1880 y de 1928, así como la Ley de Costas de 1969). La cuestión de la legitimidad de la propiedad sobre las costas, los controvertidos "enclaves privados" fue en su momento un tema polémico, complejo y, desde luego, confuso como pocos, dada la incertidumbre acerca de los cauces que, en su caso, podían amparar la adquisición legítima de estos derechos de propiedad por los particulares. Tema testigo de lo que decimos fue la polémica doctrinal sobre si la protección dispensada por el Registro de la Propiedad al tercero, en aplicación del principio de fe pública, era un medio legítimo de adquisición privada de espacios de las $\operatorname{costas}^{41}$.

Aunque los Tribunales del orden civil llegaron a admitir la legitimidad de los enclaves privados, ningún fallo judicial declararía -como ratio decidendi- la aplicación del principio de fe pública registral para amparar la propiedad privada sobre parcelas de zona marítimo-terrestre; cuando se admite la propiedad privada sobre parcelas de zona marítimo-terrestre, los controvertidos enclaves en las costas, no será en base al instituto registral de la legitimidad iure et de iure basada en la apariencia. La Sala Primera del Tribunal Supremo considerará que no era un hecho que pudiera oponerse a la condición pública de las costas que el titular inscrito reuniera los requisitos del artículo $34 \mathrm{LH}$, porque en ningún caso sobre estos bienes se perfecciona la condición del tercero hipotecario. Para llegar a este razonamiento el Tribunal Supremo se apoyaría en dos argumentos, que aparecen de forma constante en los fallos de esta época: los bienes de dominio público están fuera de comercio, llevando en su peculiar destino la propia garantía de su inalterabilidad e inmunidad y, sobre todo, al estar estos bienes exceptuados del Registro de la Propiedad el principio de fe pública no puede afectarles. En definitiva, sustentar la prohibición de acceso al Registro como expresión clara de que no necesitaban esta publicidad, precisamente por su condición notoria de ser bienes de dominio público ${ }^{42}$.

${ }^{41}$ Una exposición del estado de la cuestión acerca de los enclaves privados hasta la Ley de Costas de 1988 puede encontrarse en el trabajo El deslinde de costas. Ob. cit., págs. 231 y ss, en el que se da cuenta de las posiciones de la doctrina científica, del Consejo de Estado y de la jurisprudencia sobre los diferentes aspectos que se concitan alrededor del tema de los enclaves.

42 Entre otras, vid. SSTS: de 18 de noviembre de 1973 (RJ.4418), de 3 de junio de 1974 (R.J.6213) de 5 de diciembre de 1984 (RJ.5400), de 17 de junio de 1985 (RJ.3292), de 22 de julio de 1986 (FJ.4577) y de 10 de noviembre de 1986 (FJ.6249). 
Supuesto diferente sería el que el titular registral pudiese probar que en la cadena de títulos de los que traía causa el propio se originó uno de los motivos que fundamentaban la legitimidad del enclave, en aplicación de la conocida doctrina de "los hechos obstativos" a la demanialidad de la ribera del mar"

Por lo demás, la normativa de costas vigente, en línea directa con la Constitución, proscribe de manera contundente la propiedad privada sobre estos bienes, estableciendo que sobre las dependencias del dominio público marítimo-terrestre no podrá existir ninguna titularidad que no sea la demanial del Estado (artículo 9). Además, por si hubiera dudas, afirma expresamente que a la titularidad demanial no se le pueden oponer titularidades privadas "aunque aparezcan amparadas en asientos del Registro de la Propiedad" (artículo 8 de la Ley de Costas), lo cual es una manera gráfica de excluir la aplicación al dominio público marítimo-terrestre de la figura del tercero hipotecario ${ }^{44}$. Ahora bien, este precepto es una previsión de futuro, que prescribe la inoperancia de consolidar la condición de tercero registral; por ello, y en la medida que, como se ha expuesto, conforme a la legislación derogada se habían admitido enclaves privados, la disposición transitoria primera de la Ley establece la conversión de los derechos privados que pudieran ser legítimos en un derecho de uso y aprovechamiento. Ciertamente, para los titulares registrales sobre parcelas de la ribera del mar la norma no establecía directamente una compensación, situación que fue corregida por el Tribunal Constitucional en la Sentencia 149/1991, en el sentido de que si los titulares registrales obtienen una sentencia judicial declarando su propiedad privada automáticamente obtendrían la conversión de su derecho en la concesión administrativa en que se materializa la expropiación de su dominio que opera la Ley de Costas ${ }^{45}$. Qui-

\footnotetext{
${ }^{43}$ En este sentido, la pretensión del particular obstativa a la condición pública de la parcela de zona marítimo-terrestre solo podía prosperar, conforme a esta doctrina jurisprudencial, si se probaba inexcusablemente: a) que el terreno discutido hubiera pasado al dominio de los particulares antes de la Ley de Puertos de 1880; b) que se hubiera producido una desafectación o cambio de destino y c) que su alienabilidad hubiera sido autorizada.

${ }^{44}$ Sobre la trascendencia que al principio de fe pública registral implica el artículo 8 LC vid. R. PAREJO GAMIR, en "Aspectos registrales de la nueva Ley de Costas", en Libro Homenaje al profesor Villar Palasí. Cívitas, Madrid, 1989, pág. 987.

${ }^{45}$ La conversión en concesión administrativa del derecho de propiedad sobre parcelas de la ribera del mar solo estaba prevista en la Ley de Costas para los que contaban con una sentencia firme o aquellos cuyos bienes se encontraran entre dos deslindes. Esta situación discriminatoria fue puesta en evidencia por el Tribunal Constitucional en la sentencia citada, en tanto que la situación subyacente a la titularidad inscrita en el Registro de la Propiedad fuese la de un derecho privado
} 
zá sea esta la razón que explique como algunos Tribunales están reconociendo el derecho de propiedad sobre parcelas de las costas, considerando suficiente que el particular cuente con un derecho de dominio inscrito en el Registro de la Propiedad, a los efectos de que le sea otorgada al titular la concesión administrativa prevenida en la normativa. Pero es claro en nuestra opinión que a la luz de la legislación vigente no es posible la admisión de propiedad privada sobre los bienes del demanio marítimo-terrestre con vocación de permanencia, esto es, con la consistencia de un derecho que debe mantenerse ${ }^{46}$.

En relación con las vías pecuarias la admisión de la figura del tercero hipotecario no encuentra solución clara, ni existe ninguna previsión normativa que expresamente afronte la cuestión. Tampoco hemos encontrado en la jurisprudencia civil ningún pronunciamiento que aborde directamente si es o no de aplicación del principio de fe pública registral en el caso de tratarse de vías pecuarias. Con todo, debe reseñarse que al igual que sucediera con las costas la propiedad privada sobre vías pecuarias ha estado admitida en las normas reguladoras de estos bienes hasta la vigente Ley Básica de Vías Pecuarias de 1995 y normas de desarrollo de las Comunidades Autónomas. En efecto, aunque de manera palmaria se atribuía a las vías pecuarias el carácter de dominio público, la normativa histórica de los caminos cañadiegos reconocerían efectos a las posesiones legitimadas por el transcurso del tiempo o, en general, a los derechos de propiedad consolidados sobre terrenos que las integran ${ }^{47}$.

legítimamente adquirido. Este hecho lleva al Tribunal Constitucional a establecer una interpretación correctiva de la norma transitoria de la Ley de Costas, en el sentido de declarar que siempre puede el titular registral instar ante los Tribunales civiles la declaración de su propiedad, y caso de resolución judicial estimatoria, le sería de aplicación las previsiones dispuestas para los enclaves reconocidos por sentencia firme (F.J.8.B, apartado c de la Sentencia 149/1991, de 4 de julio).

46 Vid., nuestro trabajo "¿Resurgimiento de enclaves privados en las costas? La posibilidad de pervivencia de los enclaves privados tras la Ley 22/88, de 28 de julio, de Costas. (A propósito de la Sentencia del Tribunal Supremo de 10 de junio de 1996). R.A.A.P., núm. 31, 1997, págs. 119 y ss.

${ }^{47}$ Entre otras normas, el artículo 1 de la anterior Ley de Vías Pecuarias de 27 de junio de 1974 disponía que las vías pecuarias son bienes de dominio público y además "no son susceptibles de prescripción ni de enajenación, ni podrá alegarse para su apropiación el tiempo que hayan sido ocupadas, ni legitimarse las usurpaciones de que hayan sido objeto". Sin embargo, el problemas de la posibilidad de propiedad privada sobre las vías pecuarias, al igual que en normas anteriores, se mantiene latente en la Ley al precisar, en la disposición final primera, que: "lo dispuesto en esta Ley se entiende sin perjuicio de los derechos legalmente adquiridos que hayan hecho irreivindicables los terrenos ocupados de vías pecuarias, y cuya situaciones se apreciarán por los Tribunales de Justicia". 
Ante este dato, la doctrina que se ha ocupado del tema sostiene que en los supuestos en que la propiedad se hubiese adquirido legítimamente, atentaría al más elemental sentido jurídico no reconocer tal situación jurídica, de ahí que de verificarse la legitimidad de la propiedad privada la Administración debe expropiar si el interés público requiere que el bien mantenga la calificación de vía pecuaria y se destine a los fines que le son propios ${ }^{48}$.

La pregunta que cabe hacer, por tanto, es si la propiedad privada puede fundarse legítimamente en la figura del tercero registral, y en qué supuestos puede considerarse legítima. En este sentido, puede servir de orientación la solución que se vierte en la Sentencia de 23 de diciembre de 2003 el Tribunal Superior de Justicia de Andalucía. Debe advertirse que este fallo judicial trata la cuestión a otros fines, los de las situaciones que cabe oponer a la Administración pública en un deslinde de vía pecuaria; además, este fallo procede del orden contencioso-administrativo con lo que no vincula a los Tribunales civiles, únicos competentes para dilucidar los derechos de propiedad. Aún así, esta decisión judicial pudiera ilustrar la cuestión planteada, al señalar tres supuestos en los que ha podido originarse fundadamente un derecho de propiedad sobre terrenos integrantes de una vía pecuaria, a saber:

a) que el terreno hubiese sido enajenado o permutado en el pasado por la Administración, como permitiese la legislación derogada previa clasificación de innecesariedad y deslinde de la vía pecuaria;

b) que se hubiese legalmente usucapido terrenos cañadiegos conforme a las reglas del Código Civil; o

c) que se hubiese producido una adquisición ex lege contemplada por el artículo $34 \mathrm{LH}$, que más allá de la mera presunción de exactitud establecida por su artículo 38 comporta la adquisición inatacable de quien, confiando en el Registro de la Propiedad, compra a título oneroso y de buena fe a quien no es dueño pero figura como tal en el Registro.

En cualquier caso, esta Sentencia deja claro que los derechos privados legítimamente adquiridos que cabe reconocer, entre los cuales recoge los que traen causa en el principio de fe pública registral, tienen que haberse origi-

${ }^{48}$ En tal sentido: ALENZA GARCÍA, Vías pecuarias. Ob. cit., pág. 403; J.A. CARRILLO DONAIRE, "La intervención administrativa sobre las vías pecuarias". Ob. cit., pág. 42. 
nado antes del acto de clasificación de la vía pecuaria, pues sitúa en tal acto el momento en que los terrenos en cuestión merecen ya la consideración de dominio público. Por esta razón, en la Sentencia citada se señala que una vez que los terrenos adquieren la condición de vía pecuaria tras el acto de clasificación no podrá originarse una titularidad privada contradictoria, pues la eficacia de las normas civiles sobre adquisición de la propiedad se verá mermada, dada la protección reforzada del dominio público. En definitiva, la doctrina que se vierte en esta Sentencia descansa en un presupuesto de partida: si el bien ya es dominio público las reglas que definen la extracomerciabilidad del demanio (imprescriptibilidad, inalienabilidad e inembargabilidad) determinan la ineficacia de las normas que regulan los modos privados de adquisición de los derechos. Y en esta Sentencia se asume expresamente que el momento determinante de la condición pública tratándose de vías pecuarias es el acto de clasificación, como acto singular y expreso de su afectación al dominio público, siguiendo a la doctrina mayoritaria ${ }^{49}$.

\section{RÉGIMEN REGISTRAL DE LOS BIENES PÚBLICOS EN LA LEY DE PATRIMONIO DE LAS ADMINISTRACIONES PÚBLICAS}

\section{Obligatoriedad de la inscripción en el Registro de la Propiedad de los bie- nes y derechos públicos}

Como se señalara anteriormente la normativa registral admite el acceso al Registro de la Propiedad de los bienes y derechos públicos, ya sin distinción entre bienes de dominio público y bienes patrimoniales (artículos $2.6 \mathrm{LH}$ y 4 y $5 \mathrm{RH}$ ). Ahora bien, en nuestro sistema registral el acceso al Registro de la Propiedad del dominio y de los derechos reales sobre bienes inmuebles tiene, salvo contadas excepciones, carácter voluntario, de modo que es el interesado quien debe ponderar la conveniencia de utilizar a su favor la protección jurídica que a los derechos reporta el Registro de la Propiedad: principio de legitimación registral, principio de fe pública, juicios sumarios en defensa de los derechos inscritos, entre otros. Por tal razón, tanto la Ley como el Reglamento Hipotecario no distinguen según sea la condición del sujeto que desea acogerse al sistema de publicidad hipotecaria y confieren a la inscripción de los bienes y derechos en el Registro carácter facultativo.

49 Vid. O. HERRAIZ SERRANO, Régimen jurídico de las vías pecuarias. Comares, Granada, 2000, pág. 432 y M.A. PARRA LUCÁN. Vias pecuarias y propiedad privad. Ob. cit., pág. 212. 
La Ley de Patrimonio de las Administraciones Públicas de 3 de noviembre de 2003 (LPAP), por el contrario, prescribe la necesariedad de inscribir los bienes y derechos públicos en el Registro de la Propiedad, siguiendo la orientación de normas administrativas anteriores ${ }^{50}$. Así, conforme al artículo 36.1 LPAP, las Administraciones públicas "deben inscribir en los correspondientes registros los bienes y derechos de su patrimonio, ya sean demaniales o patrimoniales, que sean susceptibles de inscripción, así como todos los actos y contratos referidos a ellos que puedan tener acceso al dichos registros; no obstante, la inscripción será potestativa para las Administraciones públicas en el caso de arrendamientos inscribibles conforme a la legislación hipotecaria”. Debe repararse, no obstante, que tal deber está dirigido a las Administraciones públicas, como sujetos obligados a solicitar la inscripción de los derechos, de ahí que no se altere la normativa hipotecaria en el sentido de mantener la configuración clásica del carácter voluntario de la inscripción. En otras palabras, la obligatoriedad de la inscripción de los bienes y derechos públicos tiene por destinatario a las Administraciones públicas y se traduce en que éstas deben realizar todas las actuaciones tendentes a conseguir el asiento en el Registro de la Propiedad para la publicidad de sus derechos sobre bienes inmueble; pero no significa que los registradores de la propiedad tengan necesariamente que proceder a la inscripción del bien o derecho de titularidad pública si no se cumplen los requisitos tanto materiales como formales exigidos por la normativa hipotecaria. Como no podría ser de otro modo, la función calificadora del registrador de la propiedad no se ve condicionada por la regla de la obligatoriedad de la inscripción de los bienes públicos.

Dicho esto, conviene retener dos cosas. La primera, que de conformidad con el sistema de fuentes en la regulación de los bienes públicos que establece la nueva Ley de Patrimonio de las Administraciones Públicas, y en concreto el principio de especialidad que instaura (artículo 5.4 $)^{51}$, las previsiones que en

${ }^{50}$ La inscripción en el Registro de la Propiedad de los bienes públicos, abstracción hecha de su controvertida aplicación al dominio público, se ha recogido tradicionalmente en términos imperativos; en este sentido puede traerse a colación el artículo 42 de la derogada Ley de Patrimonio del Estado de 1964, y con tal carácter se establece en el artículo 36.1 del Reglamento de Bienes de las Entidades Locales de 1986: "Las Corporaciones locales deberán inscribir en el Registro de la Propiedad sus bienes inmuebles y derechos reales, de acuerdo con lo previsto en el legislación hipotecaria".

${ }^{51}$ Con independencia del carácter de normativa básica, de aplicación general o de aplicación solo para el Estado y sus organismos públicos que la Ley de Patrimonio de las Administraciones Públicas confiere a sus preceptos, el artículo 5.4 consagra el principio de especialidad de la regulación sectorial de los bienes de dominio público: "Los bienes y derechos de dominio público se 
este punto puedan existir para determinados bienes de dominio público son de aplicación preferente a la prevista en la propia Ley; en tal sentido, por ejemplo, la normativa de costas no recoge como obligatoria la inmatriculación del demanio marítimo-terrestre, que solo debe procurarse si la Administración lo estima conveniente. En segundo lugar, cabe destacar que la obligatoriedad de inscripción, en los términos vistos, se recoge, ahora sí, en una norma con rango suficiente. No está de más recordar que uno de los motivos, quizá el principal, que llevó al Tribunal Supremo a declarar nulos algunos de los preceptos del Real Decreto 1867/1998, de 4 de septiembre, de modificación del Reglamento Hipotecario fue, precisamente, que imponían con carácter preceptivo la inscripción de los bienes públicos, lo cual invadía el ámbito del régimen jurídico de los bienes de dominio público reservado a la Ley ${ }^{52}$.

Por lo demás, cabe señalar que, tratándose de bienes de dominio público, el cumplimiento de la obligación de inscripción en el Registro de la Propiedad que ahora se instaura se sujeta a un plazo de cinco años desde la entrada en vigor de la Ley, tiempo que se ha estimado suficiente para que las Administraciones públicas regularicen la situación a estos efectos de la totalidad de los bienes demaniales (disposición transitoria quinta).

Por último, el propio artículo 36 LPAP, en su apartado 2, señala a quien le corresponde la obligación de solicitar la inscripción del derecho en el Registro de la Propiedad, concretando el deber genérico de la Administración pública: el órgano que haya adquirido el bien o derecho, o que haya dictado el acto intervenido en el contrato que deba constar en el registro o, en su caso, por aquel al que corresponda su administración y gestión. Con todo, por cuanto este apartado del artículo 36 ya no es básico, las Comunidades Autónomas pueden establecer en su normativa propia cuál sea el órgano al que corresponde esta obligación de inscripción de los bienes públicos.

regirán por las leyes y disposiciones especiales que les sean de aplicación y, a falta de normas especiales, por esta Ley y las disposiciones que la desarrollen o complementen. Las normas generales del derecho administrativo y, en su defecto, las normas de derecho privado, se aplicarán como derecho supletorio".

${ }^{52}$ La Sentencia de 31 de enero de 2001 (RJ.1083) declaró nulos los artículos 6, 17 y 18 del Real Decreto 1867/1998, de modificación del Reglamento Hipotecario, por imponer con carácter imperativo la inscripción de los bienes de dominio público, dado que a juicio del Tribunal Supremo tales preceptos invadían el ámbito del régimen jurídico de los bienes de dominio público reservado a la ley. 


\section{La certificación administrativa de dominio del artículo 206 LH como títu- lo formal privilegiado de inscripción}

El acceso de los bienes públicos al Registro de la Propiedad tiene lugar con la inscripción del título de adquisición del bien a favor de la Administración titular del mismo, y en el supuesto de que el bien tenga entrada por primera vez en el Registro a esta inscripción se denomina inmatriculación. En este sentido, lo que accede al Registro de la Propiedad es el derecho de dominio sobre el inmueble a nombre de la Administración pública titular, de ahí que a tal título de adquisición del bien se le considere el título material inscribible (artículo 2.6 $\mathrm{LH}^{53}$ ). Ahora bien, para que el título material acceda al Registro de la Propiedad debe consignarse en un título formal a efectos de la inscripción, considerándose por tales: escritura pública, ejecutoria o documento auténtico expedido por autoridad judicial o por el Gobierno o sus agentes, en la forma que prescriben las normas registrales (artículos 3 LH y 33 $\mathrm{RH}^{54}$ ). A partir de estas previsiones generales la legislación hipotecaria dispone cuál o cuáles tienen el carácter de título formal válido para que se inscriba en el Registro de la Propiedad el correspondiente título material, estableciendo cuáles son los requisitos de toda índole para ello. Al título formal para la inscripción se refiere la Ley de Patrimonio de las Administraciones Públicas con el nombre de "título inscribible" en el artículo $37^{55}$.

${ }^{53}$ En este sentido el artículo 2 LH recoge los títulos materiales expresivos de la adquisición de los derechos sobre los bienes, y respecto a los bienes públicos el apartado 6 señala que se inscribirán: "los títulos de adquisición de los bienes inmuebles y derechos reales que pertenezcan al Estado, o a las corporaciones civiles o eclesiásticas, con sujeción a lo establecido en las leyes o reglamentos".

${ }^{54}$ Gráficamente el artículo 33 RH establece que "se entenderá por título, para los efectos de la inscripción, el documento o documentos públicos en que funde inmediatamente su derecho la persona a cuyo favor haya de practicarse aquélla y que hagan fe, en cuanto al contenido que sea objeto de inscripción, por sí solos o con otros complementarios, o mediante formalidades cuyo cumplimiento se acredite". En este sentido, los documentos públicos hábiles para la inscripción en el Registro de la Propiedad pueden ser: a) documentos notariales: como escrituras públicas; documentos judiciales: como sentencias, autos y providencias y c) documentos administrativos: como certificaciones administrativas.

${ }^{55}$ Sobre el tratamiento registral de la Ley de Patrimonio de las Administraciones públicas puede consultarse los trabajos de C. FERNÁNDEZ RODRÍGUEZ, "Inventario patrimonial y régimen registral", en Comentarios a la Ley 333/2003 de Patrimonio de las Administraciones Públicas, Dir. C. CHINCHILLA, Thomson-Cívitas, 2004, págs. 305 y ss.; y F. VILLALBA PÉREZ ("Del régimen registral de los bienes públicos (Artículo 36 a 40 LPAP), en El Régimen Jurídico General del Patrimonio de las Administraciones Públicas, Dir. F. MESTRE DELGADO, El Consultor, 2005, págs. 421 y ss; P. VALCÁRCEL FERNÁNDEZ, "Consideraciones sobre el acceso de los bienes públicos en el Registro de la Propiedad”, en Propiedades Públicas. Justicia Administrativa, 2006, págs. 107 y ss. 
En relación con los títulos inscribibles, debe señalarse que conforme al art. 37.1 LPAP "La inscripción en el Registro de la Propiedad se practicará de conformidad con lo prevenido en la legislación hipotecaria y en esta Ley", de ahí que con carácter general será la normativa registral la que determine cuál deba ser el título formal hábil para que se publiquen en el Registro los derechos sobre los bienes públicos, a partir de lo cual las previsiones de Ley patrimonial vienen a ser un complemento en este punto. Al respecto, cabe señalar que para permitir la inscripción en el Registro de la Propiedad de los derechos de dominio de las Administraciones públicas sobre los bienes, las normas hipotecarias han reconocido la facultad de éstas para crear, bajo ciertas condiciones, el título formal que permitiese la inscripción en los supuestos en que no contaran con otro título formal apto para ello: la certificación administrativa de dominio regulada en el artículo 206 LH. La certificación administrativa de dominio es pues un título formal válido para la inscripción, que suple la falta del título público de su adquisición, normalmente la escritura pública, y al que se equipara a estos fines.

En efecto, la Ley Hipotecaria de 1944, al igual que la normativa administrativa patrimonial ${ }^{56}$, reconocería que las Administraciones públicas pudieran inscribir sus bienes mediante certificación administrativa, librada por el funcionario a cuyo cargo esté la administración de los mismos, en los casos en que no contaran con título escrito de dominio. La certificación administrativa regulada en el artículo $206 \mathrm{LH}$ y artículos 303 y $307 \mathrm{RH}$ constituye pues un notable privilegio registral, al conformar un título válido que suple la falta de escritura pública o documento judicial inscribible a los fines de la inmatriculación de los bienes de las Administraciones públicas (artículo 199 LH).

Ahora bien, si en un primer momento esta facultad estaba reconocida a los fines de que las Administraciones públicas pudieran solicitar el asiento de inmatriculación de sus bienes, la certificación administrativa de dominio del artículo $206 \mathrm{LH}$ ha extendido progresivamente su ámbito de aplicación.

\footnotetext{
${ }^{56}$ En este sentido la derogada Ley de Patrimonio del Estado remitía al artículo 206 LH para la inscripción de sus bienes cuando el Estado careciera de título de dominio (artículo 44), igualmente la normativa local refleja este privilegio y reconoce que para inscribir los bienes públicos en el Registro de la Propiedad es "suficiente a tal efecto la certificación que, con arreglo al inventario aprobado por la respectiva Corporación expida el secretario, con el visto bueno del Alcalde o Presiente y que producirá iguales efectos que una escritura pública" (Artículo 85 del Texto Refundido de Régimen Local); especificando el Reglamento de Bienes de las Entidades Locales que en el caso de no existir título inscribible de dominio, esto es, el título formal, "se estará a lo dispuesto en el artículo 206 de la ley Hipotecaria y 303 a 307 de su Reglamento" (artículo 36. 3).
} 
En primer lugar, la reforma operada por la Ley 13/1996, de Medidas Fiscales, Administrativas y del Orden Social, de 30 de diciembre, añadirá un nuevo párrafo al artículo $206 \mathrm{LH}$, en virtud del cual la certificación administrativa de dominio es también título formal válido para que puedan inscribirse la declaración de obra nueva, mejoras y división horizontal de las fincas urbanas y, siempre que no afecten a terceros, las operaciones de agrupación, división, agregación y segregación de fincas del Estado y de los demás Entes públicos estatales certificantes.

A estas operaciones jurídicas se refiere el artículo 37.2 LPAP al establecer que la inscripción de las mismas podrá practicarse mediante la certificación administrativa prevista en el artículo $206 \mathrm{LH} \mathrm{o}$, admitiendo expresamente, además que pueda realizarse mediante traslado de la disposición administrativa en cuya virtud se verifiquen. Pueden destacarse, a tenor de este precepto, que tiene carácter de norma de aplicación general conforme a la Disposición Final 2 ${ }^{\underline{a}}$ LPAP, dos cosas: de una parte, que admite el traslado de la disposición administrativa en que se verifiquen tales operaciones como título válido para solicitar la inscripción; de otra que no se restringe ya al Estado la funcionalidad de la certificación administrativa para la inscripción de las operaciones que contempla, de ahí que quepa suponer su aplicación a todas las Administraciones públicas.

En segundo lugar, y esta es una de las novedades más importantes introducidas por la nueva Ley de Patrimonio de las Administraciones Públicas, se admite que la certificación administrativa de dominio prevista en el artículo 206 LH sea título formal válido para la reanudación del tracto sucesivo interrumpido $^{57}$. Y así, el artículo 37.3 LPAP establece que además de los medios previstos en el artículo $200 \mathrm{LH}$ (expediente de dominio y acta de notoriedad) la certificación administrativa de dominio será título válido a estos efectos siempre que se cumplan una serie de requisitos, dispuestos claramente en garantía de aquellos cuyos derechos pueden verse afectados. En este sentido, la certificación administrativa de dominio será título válido para reanudar el tracto sucesivo:

\footnotetext{
${ }^{57}$ La virtualidad de la certificación administrativa del artículo 206 LH para la reanudación del tracto interrumpido había sido propuesta por la doctrina, que ahora ha sido acogida por el legislador; en tal sentido, vid. los interesantes trabajos de P.L. SERRERA CONTRERAS, "Dos apuntes registrales en torno a la nueva Ley de Patrimonio", Revista Crítica de Derecho Inmobiliario, núm. 684, año 80, 2004, págs. 1831 y ss. y, el anterior, "La certificación administrativa de dominio y la reanudación del tracto sucesivo interrumpido", Revista Crítica de Derecho Inmobiliario, núm. 402, 1961, págs. 1081 y ss.
} 
1. Si los titulares de las inscripciones contradictorias o sus causahabientes no formulasen oposición dentro de los 30 días siguientes a aquél en que la Administración les hubiese dado traslado de la certificación que sirva para la inscripción de su derecho, bien mediante notificación personal o, si esta no es posible, mediante publicación de edictos en el tablón del Ayuntamiento y en el Boletín Oficial correspondiente.

2. Si los titulares no son conocidos, podrá inscribirse la certificación cuando las inscripciones contradictorias tenga más de 30 años de antigüedad, no hayan sufrido alteración durante ese plazo y se hayan publicado edictos, por plazo de 30 días, en los que se comunique la intención de inscribir la certificación en el tablón del Ayuntamiento y en el Boletín Oficial correspondiente, sin que se haya formulado oposición por quien acredite tener derecho sobre los bienes.

Debe señalarse que la certificación administrativa de dominio debe expresar el título de adquisición o el modo en que fueron adquiridos los derechos para los que se solicita el asiento registral, y en el caso de que se pretenda la reanudación del tracto interrumpido, además, debe expresar el tiempo que lleva la Administración titular en la posesión pacífica del bien o derecho. Igualmente, las inscripciones practicadas mediante certificación administrativa de dominio no surtirán efectos respecto de terceros hasta transcurridos 2 años (artículos 207 LH y 37.3 LPAP). Se trata de enervar durante este plazo la eficacia de la fe pública en relación con terceros adquirentes del dominio que a nombre de la Administración pública ahora publica el Registro de la Propiedad.

Por su relación con este tema, cabe indicar que la Ley de Patrimonio de las Administraciones Públicas recoge también como título formal válido para la inscripción de dominio el acto de deslinde. Y así, el artículo 53.2 LPAP dispone que "en todo caso, la resolución aprobatoria del deslinde será título suficiente para que la Administración proceda a la inmatriculación de los bienes siempre que contenga todos los demás extremos exigidos por el artículo 206 de la Ley Hipotecaria”, con una clara influencia de la normativa de montes.

\section{Disposición de los derechos inscritos en el Registro de la Propiedad a fa- vor de las Administraciones públicas y su régimen de inscripción}

La Ley de Patrimonio de las Administraciones Públicas reconoce también la eficacia de las certificaciones administrativas como título válido o formal no ya para la inscripción de sus derechos reales sobre inmuebles, como hemos visto en el apartado anterior, sino para procurar un asiento en sentido contrario, 
esto es, para rectificar inscripciones que publican derechos a su favor. Se trata de permitir que determinadas resoluciones de la Administraciones públicas, por las que se declara la inexistencia, inexactitud o extinción de sus derechos puedan acceder al Registro de la Propiedad y tengan reflejo mediante el asiento procedente. En tal dirección, el artículo 37 LPAP, en sus apartados 4 y 5 , establece los siguientes supuestos:

1. Cuando, previa la instrucción del correspondiente procedimiento en cuya tramitación será preceptiva un informe técnico, se acredite la inexistencia actual o la imposibilidad de localización física de la finca.

2. Cuando se reconozca el mejor derecho o preferencia del título de un tercero sobre el de la Administración pública en caso de doble inmatriculación del inmueble, previo informe de la Abogacía del Estado o del órgano asesor correspondiente de la Administración actuante.

3. Cuando se reconozca la titularidad, mejor derecho o preferencia del título de un tercero sobre una finca que aparezca inscrita a favor de las Administraciones públicas, previo informe de la Abogacía del Estado o del órgano asesor correspondiente de la Administración actuante.

4. Cuando en una reclamación administrativa previa a la vía judicial civil se reconozca la titularidad al interesado sobre una o varias fincas.

En todos los supuestos enumerados se contempla o la aceptación de la inexistencia del derecho, por ausencia del objeto material sobre el que recae o por la imposibilidad de liberalización, o un acto de disposición sobre el mismo por parte de la Administración pública que figura como titular del dominio del bien en el Registro de la Propiedad. Por ello, el título material para solicitar el asiento de rectificación, o de cancelación en su caso, que publica el derecho a favor de la Administración pública será la resolución administrativa en la que se declare la causa, de entre las señaladas, por la que el Registro de la Propiedad se evidencia inexacto. Cuestión distinta es el título formal necesario para la rectificación o cancelación del asiento en el Registro de la Propiedad.

Para los tres primeros supuestos, y a tenor del artículo 37.4 LPAP, bastará la certificación administrativa expedida por el órgano administrativo que tenga competencia certificante y en la que se recoja la resolución, adoptada por el órgano competente, que declare la inexistencia del derecho o reco- 
nozca que el derecho corresponde a un tercero. Este es el modo normal de actuar en las Administraciones públicas: dar traslado de la resolución o disposición administrativa, cuyo contenido se solicita reflejar en el Registro de la Propiedad, consignándola en un documento auténtico expedido por el órgano que tiene competencia para ello.

Para el último supuesto, el apartado 5 del art.37 LPAP dispone que será título bastante para la rectificación o cancelación de la inscripción a favor de la Administración pública la orden estimatoria de la reclamación previa a la vía judicial civil, una vez haya sido notificada al interesado. Parece pues que es el tercero cuya reclamación previa es estimatoria quien deberá presentar al registrador de la propiedad la resolución administrativa reconociéndole su titularidad y solicitará en consonancia con la misma la rectificación o cancelación de la inscripción que publica el dominio de la Administración pública. Con todo, en nuestra opinión, tal resolución deberá consignarse en la correspondiente certificación administrativa para que adquiera la condición de documento auténtico.

El fundamento del artículo 37 LPAP en este punto puede encontrarse en tratar de evitar el juicio civil que tendría que entablar el tercero interesado en la rectificación del asiento a favor de la Administración pública, cuando ésta reconoce sus pretensiones de fondo; desde la perspectiva del sistema hipotecario se pretende dotar de valor suficiente para la rectificación de la inscripción del derecho de la Administración pública a la certificación administrativa que consigne la decisión administrativa al respecto, permitiendo en estos casos prescindir de la escritura pública o de la sentencia judicial como títulos para la rectificación del Registro de la Propiedad (artículo $40 \mathrm{LH}$ ).

Una cuestión nada clara, a nuestro juicio, es la aplicación de estas normas a todas las Administraciones públicas, habida cuenta de que salvo error por nuestra parte la Disposición Final $2^{a}$ de esta Ley no confiere a los apartados 4 y 5 del artículo 37 LPAP ni carácter básico ni tampoco el carácter de disposición de aplicación general. ¿Significa, a tenor del artículo 2.2 LPAP, que solo se aplica a la Administración General del Estado? La redacción del precepto parece apuntar otra cosa, pues si no carecería de sentido el que se refiera a las Administraciones públicas, y no a la Administración General del Estado. Es más, no encontramos ninguna razón de fondo ni de forma para negar a las Administraciones públicas distintas de la General del Estado las facultades que reconocen estas normas en sus relaciones con el Registro de la Propiedad. El problema se agudiza por el dato de que la legislación hipotecaria, al ser parte integrante de la legislación civil, es competencia exclusiva del Estado a tenor del 
artículo 149.18 CE, de modo que no cabe la posibilidad de que Administraciones públicas distintas puedan dotarse de una normativa en parecidos términos.

\section{Deber de colaboración de los registradores de la propiedad en defensa de la integridad de los bienes públicos}

No es preciso insistir que en nuestro país el Registro de la Propiedad es un instrumento útil, quizá el principal, en garantía de la propiedad inmobiliaria privada y, por derivación, de la seguridad del tráfico. Por esta razón las normas sobre bienes públicos han ido estableciendo medidas de diversa índole dirigidas a hacer del Registro de la Propiedad un instrumento útil también para la defensa de la integridad de los bienes públicos, en torno a las cuáles se ha ido construyendo un deber de colaboración por parte de la figura del registrador de la propiedad. La finalidad de estas normas es articular medidas precautorias en pro de la defensa de la integridad de los bienes y derechos públicos, e implicando en tal cometido a los registradores de la propiedad.

Si se estima, como hacemos, que la medida más efectiva para la protección de los bienes públicos es la posibilidad, cuando no la obligación, de la inscripción de los mismos en el Registro de la Propiedad, se explicaría que la primera actuación que comprende este deber de colaboración de los registradores de la propiedad consista en la llamada promoción de la debida inscripción. De aplicación ahora a todos los bienes y derechos públicos y en beneficio de todas las Administraciones públicas, este deber se recoge actualmente en el artículo 39 LPAP: los registradores de la propiedad cuando tengan conocimiento de la existencia de bienes y derechos pertenecientes a las Administraciones públicas que no estuviesen inscritos debidamente, lo comunicarán a los órganos a los que corresponda su administración, para que por estos se inste lo que proceda ${ }^{58}$.

Además del acceso al Registro de la Propiedad de los bienes públicos, las normativa patrimonial vigente recoge otras medidas que tratan de evitar que puedan surgir derechos contradictorios a la condición y titularidad pública de los bienes, en especial titularidades de dominio a favor de terceros. Estas medidas implican una colaboración necesaria, de distinta intensidad según los casos, por parte del registrador de la propiedad al punto de que en su función calificadora, además de velar por la legalidad hipotecaria, adopten una postura defensiva frente a posibles atentados a la integridad de los bienes públicos.

\footnotetext{
${ }^{58}$ Estas normas tienen un precedente claro en los artículos 46 y 47 de la derogada Ley de Patrimonio del Estado.
} 
En esta dirección, y con carácter de norma de aplicación general, el artículo 38 LPAP establece la obligación del registrador de la propiedad de poner en conocimiento de la Administración pública inscripciones registrales sobre fincas que, por razón de su colindancia, puedan encubrir atentados a la integridad de la propiedad pública. Las inscripciones que deben comunicarse son:

a) la primera inscripción o inmatriculación de fincas colindantes con otras pertenecientes a una Administración pública; y

b) inscripciones de exceso de cabida de fincas colindantes con otras pertenecientes a una Administración pública.

En la comunicación que debe cursar el registrador de la propiedad se deberá expresar el nombre, apellidos y domicilio, si constare, de la persona o personas a cuyo favor se practicó la inscripción, la descripción de la finca y la mayor cabida inscrita, en su caso.

Con todo, en estos casos, la comunicación que a la Administración pública debe realizar el registrador de la propiedad es una actuación que no cierra el Registro, toda vez que no se impide que se realicen las inscripciones registrales citadas sobre fincas colindantes con otras de la Administración pública. El sentido pues de esta comunicación es permitir a la Administración titular verificar si el derecho que publica el Registro a consecuencia de la inscripción practicada sobre la finca privada respeta al bien público en su existencia y extensión -cabida, linderos, etc-., y en su caso ponga en marcha las actuaciones necesarias en defensa de sus bienes. Lo cual hay que ponerlo en conexión con la limitación que a tales inscripciones de exceso de cabida y de inmatriculación a favor del particular prescribe el artículo 38 LPAP por remisión al artículo 207 LH, de tal suerte que estas inscripciones no surtirán efecto respecto de tercero hasta transcurridos dos años desde su fecha. Se trata de dar tiempo a la Administración para que pueda reaccionar ante una inscripción que atente a sus derechos, pues durante dos años no podrá surgir la figura del tercero del artículo $34 \mathrm{LH}$.

Quizás en este punto la regulación más proteccionista se haya encontrado tradicionalmente en la normativa de montes públicos, que después se acogerá para las costas. En efecto, tratándose de montes de dominio público y de bienes del dominio público marítimo-terrestre las inscripciones de exceso de cabida y las inmatriculaciones de bienes de propiedad privada colindantes con aquellos deben contar con una certificación del órgano administrativo pertinente expresiva de la no invasión del bien público, pues en otro caso no es posible practicar la inscripción en el Registro de la Propiedad. La ausencia de dicha certificación, expresa o presunta, cierra el Registro de la Propiedad a la inscripción solicitada por el sujeto privado (artículos 15 de la Ley de Costas y 30 de la Ley de Montes). 